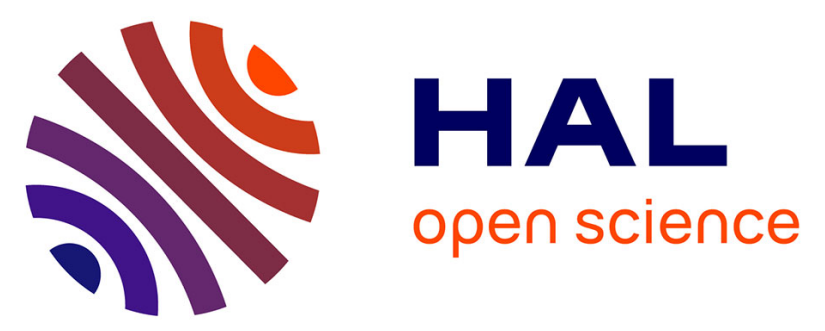

\title{
Inter- and Intramolecular Hydroamination of Unactivated Alkenes Catalysed by a Combination of Copper and Silver Salts: The Unveiling of a Brønstedt Acid Catalysis
}

Christophe Michon, Florian Medina, Frédéric Capet, Pascal Roussel, Francine Agbossou-Niedercorn

\section{To cite this version:}

Christophe Michon, Florian Medina, Frédéric Capet, Pascal Roussel, Francine Agbossou-Niedercorn. Inter- and Intramolecular Hydroamination of Unactivated Alkenes Catalysed by a Combination of Copper and Silver Salts: The Unveiling of a Brønstedt Acid Catalysis. Advanced Synthesis and Catalysis, 2010, 352 (18), pp.3293 - 3305. 10.1002/adsc.201000536 . hal-01717881

\author{
HAL Id: hal-01717881 \\ https://hal.science/hal-01717881
}

Submitted on 2 Jan 2022

HAL is a multi-disciplinary open access archive for the deposit and dissemination of scientific research documents, whether they are published or not. The documents may come from teaching and research institutions in France or abroad, or from public or private research centers.
L'archive ouverte pluridisciplinaire HAL, est destinée au dépôt et à la diffusion de documents scientifiques de niveau recherche, publiés ou non, émanant des établissements d'enseignement et de recherche français ou étrangers, des laboratoires publics ou privés. 


\title{
Inter- and intramolecular hydroamination of unactivated alkenes catalysed by a combination of copper and silver salts: the unveiling of a Brønsted acid catalysis.
}

\author{
Christophe Michon ${ }^{\mathrm{a}, \mathrm{b}, \mathrm{c} *}$, Florian Medina ${ }^{\mathrm{a}, \mathrm{b}, \mathrm{c}},{\text { Frédéric } \text { Capet }^{\mathrm{a}, \mathrm{b}, \mathrm{d}} \text {, Pascal Roussel }}^{\mathrm{a}, \mathrm{b}, \mathrm{d}}$, \\ Francine Agbossou-Niedercorn ${ }^{\mathrm{a}, \mathrm{b}, \mathrm{c} *}$ \\ a Université Lille Nord de France, 59000 Lille, France \\ b CNRS, UCCS UMR 8181, 59655 Villeneuve d'Ascq, France \\ c ENSCL, CCCF, (Chimie-C7) BP 90108, 59652 Villeneuve d'Ascq Cedex, France \\ Fax : +33-320436585, Email : christophe.michon@ensc-lille.fr, francine.agbossou@ensc-lille.fr \\ d ENSCL, CS, (Chimie-C7) BP 90108, 59652 Villeneuve d'Ascq Cedex, France (for X-ray diffraction requests) \\ Fax : +33-320436814, Email : pascal.roussel@ensc-lille.fr
}

Supporting information for this article is available free of charge on the web

Abstract : The combined use of a copper halide, a silver salt and a phosphane ligand was applied for the catalysis of interand intramolecular hydroamination of alkenes. The reactions of unactivated olefins with nitrogen substrates were investigated. Mechanistic investigations demonstrated that the catalytic system generated a Brønsted acid which appeared to be the prominent catalytic species. Keywords: hydroamination; alkenes; copper; silver salts; Brønsted acid.

\section{Introduction}

Amines are ubiquitous in natural products, building blocks or targets for fine chemicals, farming related chemicals and biologically active compounds ${ }^{[1]}$. The hydroamination of unactivated alkenes is the shortest synthetic way to secondary and tertiary amines. That atom-economic reaction can be performed on unactivated alkenes according three methods: radical transfer ${ }^{[2]}$, metal-catalysis ${ }^{[1,3,4]}$ and acid-catalysis ${ }^{[4,5,6]}$. That last method can imply a pure Brønstedt acid ${ }^{[5,6]}$ or the combination of a metal and an $\operatorname{acid}^{[3]}$. For the enantioselective synthesis of optically pure amines, the most studied and privileged hydroamination method is metal-catalysis. Lanthanides and actinides (f-block) were widely screened and significant achievements were reported for intramolecular reactions. By comparison, applications in asymmetric catalysis of transition metals from groups 3-11 (dblock) remain scarce and that's where the hydroamination challenge seems to be. Moreover, the development of recoverable catalysts may favour groups 3-11 metals which may form stable and easy to handle organometallic catalysts.

Recently, group 11 metals have been highlighted by various contributions. The usefulness of gold was pointed out on alkene $\mathrm{e}^{[7]}$ and allene ${ }^{[8]}$ substrates for both intra- and intermolecular hydroamination reactions as well as for diaminations. Silver was recently shown to be active for hydroamination of alkenes ${ }^{[9]}$. Copper was successfully used for diamination $^{[10]}$ and carboamination ${ }^{[11]}$ reactions, but it was less applied for hydroamination. Hii et all.

reported on the use of copper triflates in intermolecular reactions between vinyl arenes and amines $^{[12]}$. Gunnoe et all. applied NHC-Cu-amido complexes to the intermolecular addition of amines to activated olefins ${ }^{[13]}$. Recently, Sawamura et all. reported the efficiency of a copper-alkoxyde catalyst in various intramolecular hydroamination reactions ${ }^{[14]}$.

Following the past interest of some of us on amination reactions ${ }^{[15]}$, we started studying the use of copper catalysts in hydroamination. Initially, alkene coordination to copper complexes was extensively studied $^{[16]}$ for various applications like biomimetic models for the ethylene receptor site of plants ${ }^{[17]}$. Interestingly, Okamoto et all. ${ }^{[18]}$ used copper-halide complexes for the catalysed intramolecular hydroamination of allenylamines.

Relying on the Dewar-Chatt-Duncanson model of olefin bonding ${ }^{[19]}$, the activation of alkenes by metals can be rationalised. We assumed that copper cationic or dicationic species coordinated to $\pi$-acceptor ligands would exhibit reduced $\pi$-backdonation on the coordinated olefins which would consequently be more reactive. Hence, such cationic copper catalysts would be of interest for hydroamination reactions.

Herein, we would like to report on our investigations of the combined use of phosphanes, copper halides and silver salts applied to the catalysis of inter- and intramolecular hydroamination reactions. 


\section{Results and discussion}

\section{Reactivity Studies}

The reaction of norbornene with tosylamine was used as a model to optimise the experimental conditions, the exo-addition product ${ }^{[20]} \mathbf{3 a}$ (Table 1) being formed selectively. Regarding the metal source, copper(II) bromide led to higher conversion than copper(II) chloride when $\mathrm{AgBF}_{4}$ was used. The use of a glovebox for transfers improved drastically the yields, demonstrating the negative impact of water. Then, various phosphane ligands were screened (Table 1). 1,2-bis(diphenylphosphino)ethane, e.g. dppe (entry 4), showed to be the most efficient, even if conversion was higher without the use of any phosphane ligand (entry 7).

Table 1. Phosphane ligand screening.

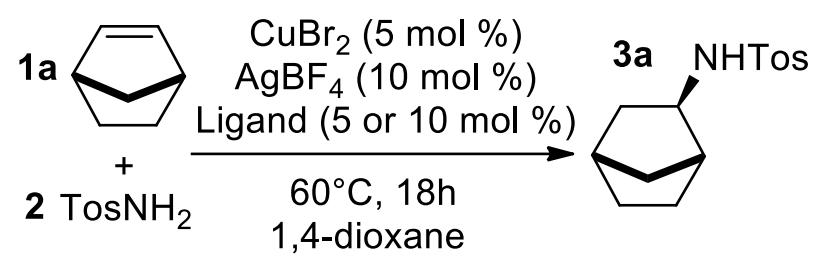

\begin{tabular}{cccc}
\hline Entry & Ligand & $\begin{array}{c}\text { Loading } \\
(\mathbf{m o l} \%)\end{array}$ & $\begin{array}{c}\text { Conversion } \\
(\%)^{\mathbf{a}}\end{array}$ \\
\hline 1 & $\mathrm{P}(\mathrm{OPh})_{3}$ & 10 & 5 \\
2 & $\mathrm{P}(\mathrm{Ph})_{3}$ & 10 & 30 \\
3 & $\mathrm{PCy}_{3}$ & 10 & - \\
4 & dppe & 5 & 80 \\
5 & dppeO & 5 & 20 \\
6 & $\mathrm{dppb}$ & 5 & 5 \\
7 & - & - & $>95$ \\
8 & $\mathrm{P}\left(\mathrm{C}_{6} \mathrm{H}_{4} \mathrm{~F}\right)_{3}$ & 5 & 18 \\
9 & $\mathrm{P}\left(\mathrm{C}_{6} \mathrm{~F}_{5}\right)_{3}$ & 5 & 16 \\
10 & Xantphos & 5 & 34 \\
11 & Davephos & 5 & 0 \\
\hline a) Conversion determined by GC.
\end{tabular}

Screening of silver(I) salts confirmed the less coordinating the anion was, the higher the conversions were (Table 2). Activity decreased according the order: $\mathrm{SbF}_{6}^{-}>\mathrm{TfO}^{-}>>\mathrm{PF}_{6}^{-}>\mathrm{NTf}_{2}^{-}>>$ $\mathrm{ClO}_{4}^{-}>\mathrm{BF}_{4}^{-}>>\mathrm{BARF}^{-}$. Surprisingly, BARF- salts led to poor conversions (entries 9-10). Silver cation confirmed to be the most appropriate as compared to alkaline-earth salts (entries 2, 9). As expected, no conversion was observed using silverbenzoate (entry 7 ), benzoate anion coordinating most probably to copper $^{[21]}$.
Table 2. Silver- and related salts screening.

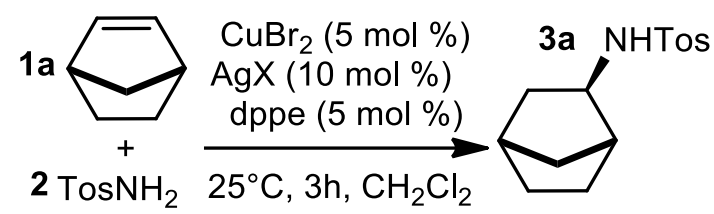

\begin{tabular}{ccc}
\hline Entry & $\mathbf{A g X}$ & Conversiona $^{\mathbf{a}} \mathbf{( \% )}$ \\
\hline 1 & $\mathrm{AgBF}_{4}$ & 47 \\
2 & $\mathrm{NaBF}_{4}$ & 0 \\
3 & $\mathrm{AgPF}_{6}$ & 75 \\
4 & $\mathrm{AgSbF}_{6}$ & $>95$ \\
5 & $\mathrm{AgOTf}$ & 95 \\
6 & $\mathrm{AgClO}_{4}$ & 45 \\
7 & $\mathrm{AgPhCO}_{2}$ & 0 \\
8 & $\mathrm{AgN}(\mathrm{Tf})_{2}$ & 68 \\
9 & $\mathrm{KBARF}$ & 9 \\
10 & $\mathrm{AgBARF}$ & 5 \\
\hline a) Conversion determined by GC. Average of 2 runs.
\end{tabular}

Table 3. Solvent screening.

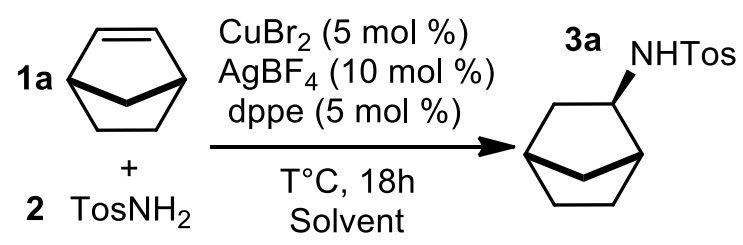

\begin{tabular}{cccc}
\hline Entry & Solvent & $\begin{array}{c}\mathbf{T} \\
\left({ }^{\circ} \mathbf{C}\right)\end{array}$ & $\begin{array}{c}\text { Conv. }^{\mathbf{a}} \\
(\mathbf{\%})\end{array}$ \\
\hline 1 & Toluene & 60 & 90 \\
2 & $"$ & 25 & 70 \\
3 & 1,2-dichloroethane & 60 & 95 \\
4 & " & 25 & 85 \\
5 & $1,1^{\prime}, 2,2^{\prime}-$ & 25 & $>95$ \\
& tetrachloroethane & & \\
6 & " & 60 & $>95$ \\
7 & Dichloromethane & 25 & $>95$ \\
8 & Chloroform & 25 & 25 \\
9 & Diethyl ether & 25 & - \\
10 & THF & 60 & 5 \\
11 & DME & 60 & 30 \\
12 & CH ${ }_{3}$ CN & 60 & 70 \\
13 & 1,4-Dioxane & 60 & 80 \\
\hline
\end{tabular}

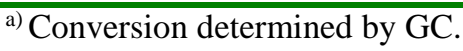

Among the various solvents screened (Table 3), 1, 1', 2, 2'-tetrachloroethane (entries 5, 6) showed to be the most interesting considering its polarity and high boiling point. Other chlorinated solvents were also suitable (entries $3,4,7,8$ ) with the exception of chloroform. Toluene (entries 1,2) and 1,4-dioxane (entry 13) led to good conversions as well. 
Next, various olefins were allowed to react with tosylamine in the presence of either copper(I)- or copper(II)-bromide in combination with $\mathrm{AgSbF}_{6}$ and dppe (Table 4). As a general trend, copper(II)bromide proved to be more reactive than copper(I)bromide as reactions were requiring less time and lower temperatures. This was observed in the case of cyclohexene (entry 3 ) and norbornene which lead to the exclusive formation of an exo product (entry 1). Otherwise, dihydrofurane showed no reactivity (entry 7). Branched "Markovnikov" products were obtained for vinylcyclohexane (entry 4), and allylbenzene (entry 5). Reaction of $n$-hexene (entry 2) proceeded well with some isomerised product resulting from the addition on position $3^{[3 \mathrm{~h}]}$. With the exception of 2vinylpyridine leading to linear "anti-Markovnikov" product (entry 6), conjugated olefins (e.g. styrene, 1,3-cyclohexadiene, 4-vinylpyridine) didn't react (entries 8-10).

To check the range of applicable nucleophiles, various amine derivatives were allowed to react with norbornene (Table 5). Exo-addition products were exclusively formed as confirmed by NMR ${ }^{[20]}$. Benzyland methyl-carbamates (entries 3-4), para-nitroaniline (entry 5) and oxazolidone (entry 7) provided the related hydroamination products in good yields. For amides, whereas no reactivity was noticed for acetamide (entry 1) and trifluoroacetamide (entry 8), benzamide (entry 9) gave the hydroamination product in modest yield and an improved conversion was found for chloroacetamide (entry 2). Benzylamine, $\mathrm{N}, \mathrm{N}$-dimethylurea and succinimide (entries 11,12 and 13) didn't react, nor phtalimide and hydrazones. Moreover, stronger nucleophiles like morpholine, di$n$-propylamine or butylamine didn't react with any screened olefins. Finally, weak basic amines didn't react with cyclohexene (see supporting information). Hence, the range of reacting nucleophiles and olefins proved to be quite narrow using such catalyst.

\section{Mechanistic investigations.}

We were particularly interested by two other results. First, benzotriazole reacted with norbornene to afford, in moderate yields, two hydroamination products $\mathbf{5 f _ { 1 }}$ and $\mathbf{5 f}_{2}$ (Table 5-entry 6 and Scheme 1). Such reaction implying triazole-derivatives is usually performed by an acid-catalysis ${ }^{[22]}$.

Second, the reaction between aniline and norbornene lead to a mixture of hydroamination and FriedelCrafts alkylation products, $\mathbf{5} \mathbf{j}_{\mathbf{1}}$ and $\mathbf{5} \mathbf{j}_{\mathbf{2}}$ (Table 5-entry 10 and Scheme 2) without any product resulting from a Hofmann-Martius rearrangement ${ }^{[6 \mathrm{k}]}$. Hydroarylation products like $\mathbf{5} \mathbf{j}_{2}$ are typical for hydroamination reactions using an acid ${ }^{[5,6,23 \mathrm{e}-\mathrm{g}]}$ or metal-acid ${ }^{[3,23 \mathrm{a}-\mathrm{d}, 23 \mathrm{f}-\mathrm{g}]}$ catalyst. At that point, we started suspecting the generation of acid along our hydroamination reactions and performed control experiments.

Scheme 1. Reactivity of benzotriazole with norbornene.

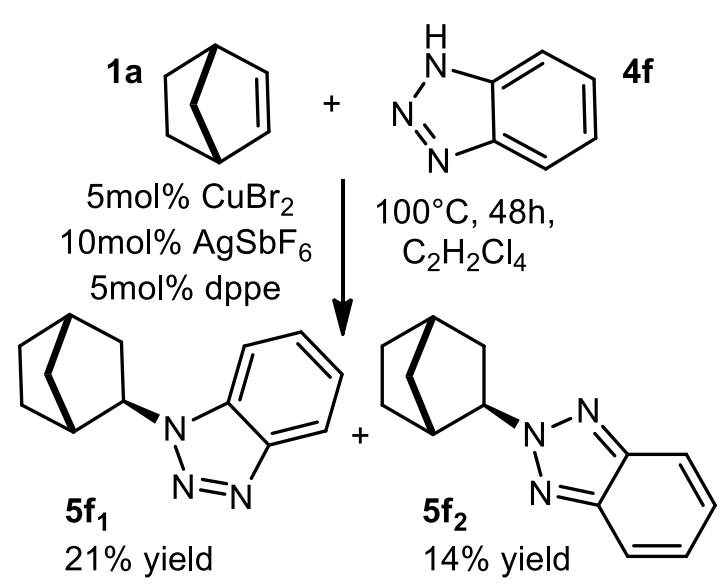

Scheme 2. Reactivity of aniline with norbornene.

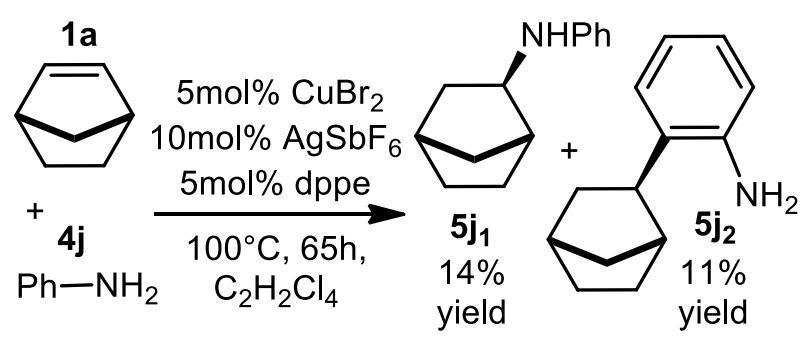

Table 6 shows the effects of additives on the hydroamination reaction of norbornene with tosylamine catalysed by a combination of copper(II)bromide and $\mathrm{AgBF}_{4}$. Reaction could be stopped by the addition of an inorganic base like $\mathrm{Cs}_{2} \mathrm{CO}_{3}$ (entry 3 ), an organic base like triethylamine (entry 4) or the non-coordinative base 2,6-di-tert-butyl-pyridine (entry 2). The use of a weak Lewis and Brønstedt base like phenothiazine decreased the yield to $29 \%$ (entry 5). Phenothiazine is also known as a radical polymerization inhibitor ${ }^{[24 a]}$ but such property might not be applicable here. Addition of another proton scavenger like calcium hydride decreased the yield to $10 \%$ (entry 6). We should also recall that reaction didn't proceed well in THF (5\% conversion, Table 3entry 6) which can be considered as a Lewis basic and coordinating solvent.

These results supported that some acid $\left(\mathrm{HBF}_{4}\right)$ was formed during the hydroamination reaction. The use of a proton source like hydroquinone (entry 7) which can reduce $\mathrm{Cu}$ (II) inhibited the reaction. 
Table 4. Olefin reactivities with tosylamine.

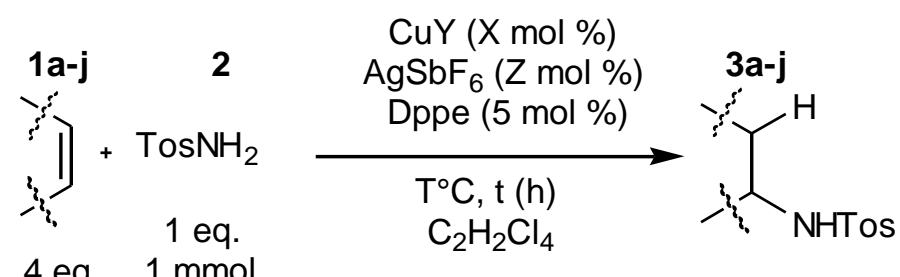

\begin{tabular}{|c|c|c|c|c|c|c|}
\hline Entry & $\begin{array}{c}\text { Alkene } \\
1 \mathbf{a}-\mathbf{j}\end{array}$ & $\begin{array}{c}\text { Copper salt } \\
(\text { mol \%) }\end{array}$ & $\begin{array}{c}\text { Silver salt } \\
(\mathrm{mol} \%)\end{array}$ & $\begin{array}{c}\text { Time } \\
\text { (h) }\end{array}$ & $\begin{array}{c}\mathbf{T} \\
\left({ }^{\circ} \mathbf{C}\right) \\
\end{array}$ & $\begin{array}{c}\text { Isolated yield }^{\mathrm{a}} \\
(\%) \mathbf{a} \text { a-j }\end{array}$ \\
\hline 1 & & $\begin{array}{l}\mathrm{CuBr}_{2}(5) \\
\mathrm{CuBr}(5)\end{array}$ & $\begin{array}{c}\operatorname{AgSbF}_{6}(10) \\
\operatorname{AgSbF}_{6}(5)\end{array}$ & $\begin{array}{c}3 \\
20\end{array}$ & $\begin{array}{c}25 \\
100\end{array}$ & $\begin{array}{l}95(\text { exo })^{\mathrm{b}} \\
95(\mathrm{exo})^{\mathrm{b}}\end{array}$ \\
\hline 2 & 1b & $\begin{array}{l}\mathrm{CuBr}_{2}(5) \\
\mathrm{CuBr}(5)\end{array}$ & $\begin{array}{c}\operatorname{AgSbF}_{6}(10) \\
\operatorname{AgSbF}_{6}(5)\end{array}$ & 20 & $\begin{array}{l}100 \\
100 \\
150\end{array}$ & $\begin{array}{c}90(4 / 6)^{\mathrm{c}} \\
2 \\
<5\end{array}$ \\
\hline 3 & & $\begin{array}{l}\mathrm{CuBr}_{2}(5) \\
\mathrm{CuBr}(5)\end{array}$ & $\begin{array}{c}\operatorname{AgSbF}_{6}(10) \\
\operatorname{AgSbF}_{6}(5)\end{array}$ & 20 & $\begin{array}{l}100 \\
100 \\
150\end{array}$ & $\begin{array}{l}96 \\
57 \\
82\end{array}$ \\
\hline 4 & & $\begin{array}{l}\mathrm{CuBr}_{2}(5) \\
\mathrm{CuBr}(5)\end{array}$ & $\begin{array}{c}\operatorname{AgSbF}_{6}(10) \\
\operatorname{AgSbF}_{6}(5)\end{array}$ & $\begin{array}{l}30 \\
20\end{array}$ & $\begin{array}{l}100 \\
100 \\
150\end{array}$ & $\begin{array}{l}\left.50{\text { (branched })^{\mathrm{d}}}^{\mathrm{d}}{\text { (branched })^{\mathrm{d}}}^{\mathrm{d}}\right)^{\mathrm{b}} \\
20 \text { (branched }^{\mathrm{d}}\end{array}$ \\
\hline 5 & & $\begin{array}{l}\mathrm{CuBr}_{2}(5) \\
\mathrm{CuBr}(5)\end{array}$ & $\begin{array}{c}\operatorname{AgSbF}_{6}(10) \\
\operatorname{AgSbF}_{6}(5)\end{array}$ & $\begin{array}{l}48 \\
20\end{array}$ & $\begin{array}{l}100 \\
100 \\
150\end{array}$ & $\begin{array}{l}88 \text { (branched) }^{\mathrm{d}} \\
21 \text { (branched) }^{\mathrm{d}} \\
25 \text { (branched) }^{\mathrm{d}}\end{array}$ \\
\hline 6 & & $\begin{array}{l}\mathrm{CuBr}_{2}(5) \\
\mathrm{CuBr}(5)\end{array}$ & $\begin{array}{c}\mathrm{AgSbF}_{6}(10) \\
\mathrm{AgSbF}_{6}(5)\end{array}$ & 20 & $\begin{array}{l}100 \\
100 \\
150\end{array}$ & $\begin{array}{c}16 \text { (linear) }^{\mathrm{e}} \\
10 \text { (linear) }^{\mathrm{e}} \\
0\end{array}$ \\
\hline 7 & & $\begin{array}{l}\mathrm{CuBr}_{2}(5) \\
\mathrm{CuBr}(5)\end{array}$ & $\begin{array}{c}\operatorname{AgSbF}_{6}(10) \\
\operatorname{AgSbF}_{6}(5)\end{array}$ & 24 & $\begin{array}{l}100 \\
100 \\
150\end{array}$ & $\begin{array}{l}0 \\
0 \\
0\end{array}$ \\
\hline 8 & & $\begin{array}{l}\mathrm{CuBr}_{2}(5) \\
\mathrm{CuBr}(5)\end{array}$ & $\begin{array}{c}\operatorname{AgSbF}_{6}(10) \\
\operatorname{AgSbF}_{6}(5)\end{array}$ & $\begin{array}{l}30 \\
20\end{array}$ & $\begin{array}{l}100 \\
150\end{array}$ & $\begin{array}{l}0 \\
0\end{array}$ \\
\hline 9 & & $\mathrm{CuBr}_{2}(5)$ & $\mathrm{AgSbF}_{6}(10)$ & 20 & 100 & 0 \\
\hline 10 & & $\begin{array}{l}\mathrm{CuBr}_{2}(5) \\
\mathrm{CuBr}(5)\end{array}$ & $\begin{array}{c}\operatorname{AgSbF}_{6}(10) \\
\operatorname{AgSbF}_{6}(5)\end{array}$ & $\begin{array}{l}20 \\
20\end{array}$ & $\begin{array}{l}100 \\
150\end{array}$ & $\begin{array}{l}0 \\
0\end{array}$ \\
\hline
\end{tabular}

a) Average of 2 runs.

b) Exo-product as shown by NMR.

c) Branched/isomerised ratio of 4/6 shown by NMR (isomerization by $\mathrm{TosNH}_{2}$ addition on position 3 of $n$ hexene).

d) Branched product from Markovnikov addition.

e) Linear product from anti-Markovnikov addition. 
Table 5. Amine substrate reactivities with norbornene.

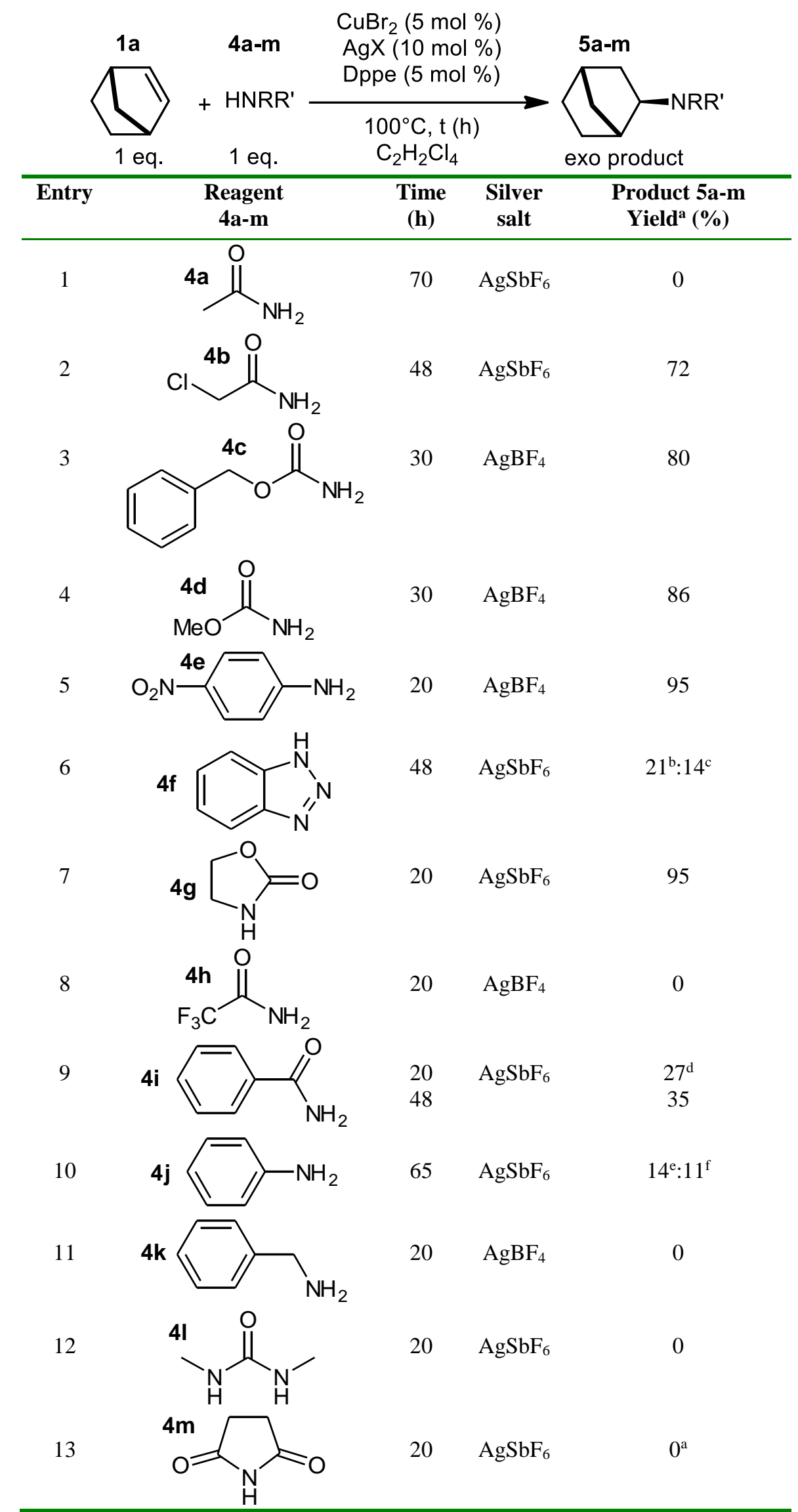

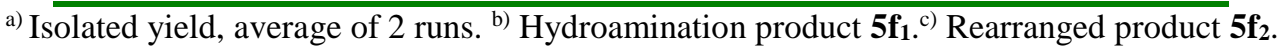

d) At $150{ }^{\circ} \mathrm{C} .{ }^{\text {e) }}$ Hydroamination product $\mathbf{5} \mathbf{j}_{1} .{ }^{\text {f) }}$ Arylation product $\mathbf{5} \mathbf{j} 2$. 
Table 6. Additive effects on $\mathrm{Cu}(\mathrm{II})$ and Silver(I) salts catalysed reaction of norbornene with tosylamine.

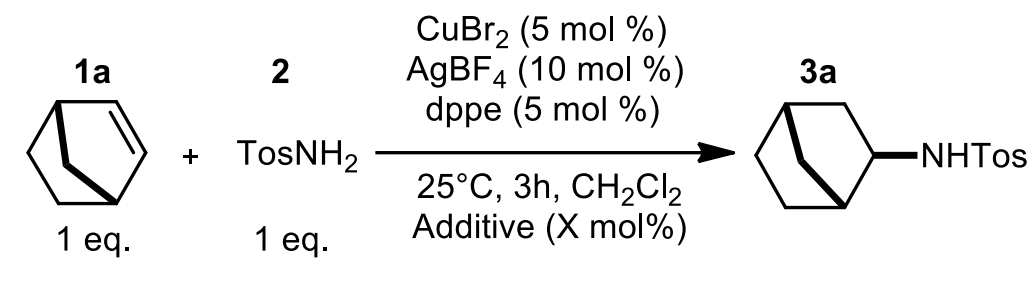

\begin{tabular}{|c|c|c|}
\hline Entry & Additive (mol\%) & Conversion $^{\mathrm{a}}(\%)$ \\
\hline 1 & No additive & 47 \\
\hline 2 & 2,6-Bis (t-Butyl)-pyridine (5.5) & 0 \\
\hline 3 & $\mathrm{Cs}_{2} \mathrm{CO}_{3}(5)$ & 0 \\
\hline 4 & $\mathrm{NEt}_{3}(5)$ & 0 \\
\hline 5 & Phenothiazine (25) & 29 \\
\hline 6 & $\mathrm{CaH}_{2}(10)$ & 10 \\
\hline 7 & Hydroquinone (5) & 15 \\
\hline 8 & Benzoquinone (5) & 2 \\
\hline 9 & TEMPO (5) & 0 \\
\hline 10 & $\mathrm{PhSiMe}_{3}(1$ eq) & 0 \\
\hline 11 & $\mathrm{HBF}_{4} . \mathrm{OMe}_{2}(5)$ & 92 \\
\hline 12 & $\mathrm{HBF}_{4} \cdot \mathrm{OMe}_{2}(5)^{\mathrm{b}}$ & $75^{\mathrm{b}}$ \\
\hline
\end{tabular}

a) measured by GC, average of 2 runs.

b) conversion with $5 \mathrm{~mol}^{2} \mathrm{HBF}_{4}$ alone, without use of $\left[\mathrm{CuBr}_{2}+\mathrm{AgBF}_{4}+\mathrm{dppe}\right]$.

Table 7. Additive effects on $\mathrm{Cu}(\mathrm{I})$ and Silver(I) salts catalysed reaction of cyclohexene with tosylamine.

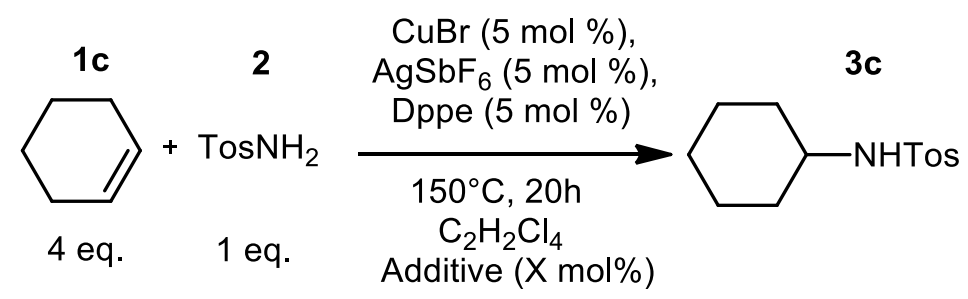

\begin{tabular}{|c|c|c|}
\hline Entry & Additive (loading mol \%) & Isolated yield $^{\mathrm{a}}(\%)$ \\
\hline 1 & None & 82 \\
\hline 2 & $\mathrm{Cs}_{2} \mathrm{CO}_{3}(5)$ & 0 \\
\hline 3 & 2,6-Bis (t-Butyl)-pyridine (5.5) & 0 \\
\hline 4 & Phenothiazine (25) & 0 \\
\hline 5 & TEMPO (5) & 0 \\
\hline 6 & $\mathrm{CaH}_{2}(10)$ & 32 \\
\hline 8 & Hydroquinone (5) & 23 \\
\hline 10 & Benzoquinone (5) & 0 \\
\hline 11 & $\mathrm{PhSi}(\mathrm{Me})_{3} \quad$ (1eq.) & 0 \\
\hline 12 & $\mathrm{HBF}_{4} \cdot \mathrm{OMe}_{2}(5)$ & 90 \\
\hline 13 & $\mathrm{HBF}_{4} \cdot \mathrm{OMe}_{2}(5)^{\mathrm{b}}$ & $50^{\mathrm{b}}$ \\
\hline
\end{tabular}

a) Average of 2 runs.

b) reaction with $5 \mathrm{~mol} \% \mathrm{HBF}_{4}$ alone, without use of $\left[\mathrm{CuBr}_{2}+\mathrm{AgBF}_{4}+\mathrm{dppe}\right]$. 
Scheme 3. Proposed reaction pathways for intermolecular hydroamination reactions.
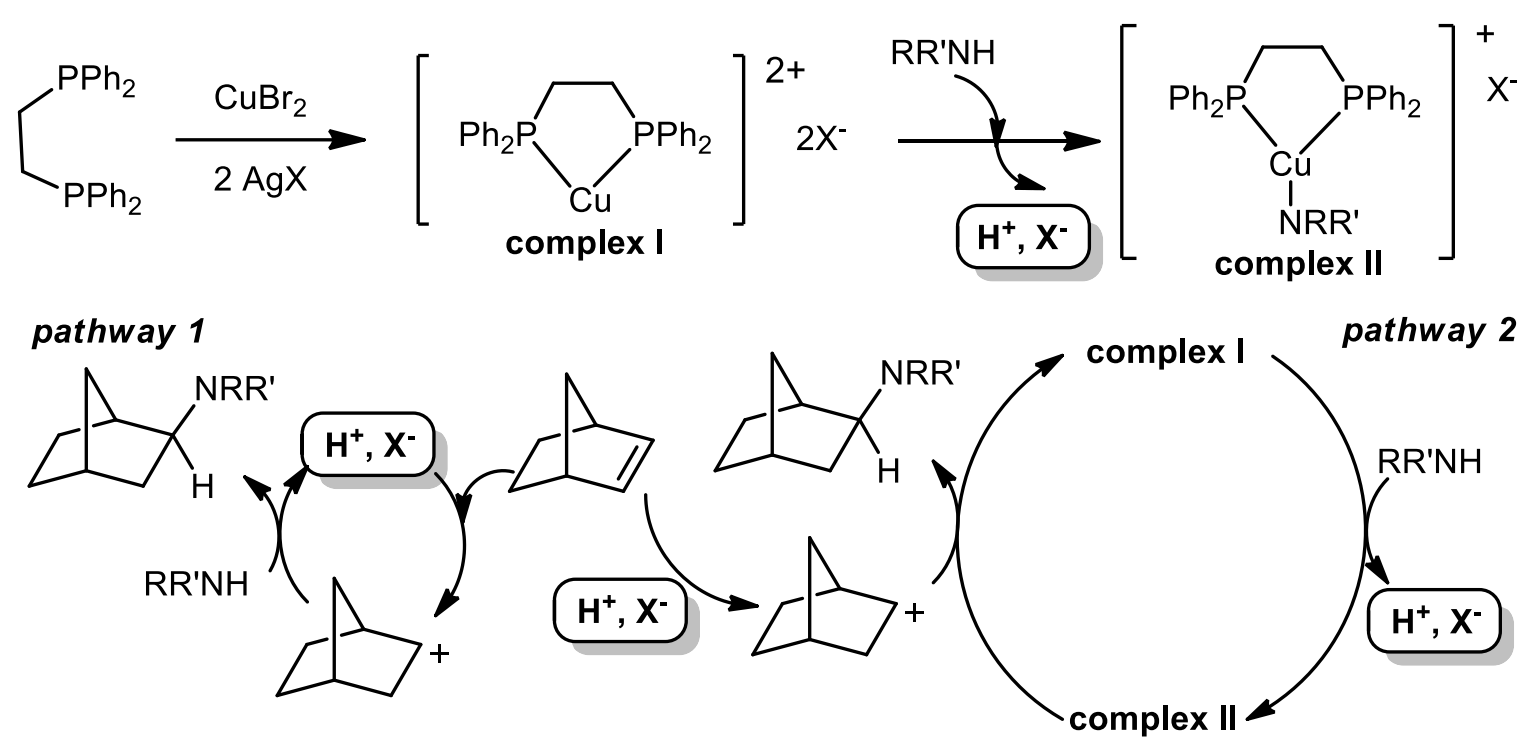

This suggests that the dicationic copper complex may be involved in the reaction process. Unlike benzoquinone (entry 8), triethylamine (entry 4) can be considered as a reducing agent ${ }^{[24 b]}$; none of these reagents allowed the reaction to occur. Otherwise, a radical scavenger like TEMPO (entry 9) inhibited the reaction. But TEMPO is also known to react irreversibly with acids by disproportionation ${ }^{[24 c]}$. The addition of a proton trap like $\mathrm{PhSi}(\mathrm{Me})_{3}$ (entry 11) stopped the reaction and confirmed the presence of free protons in the reaction medium. It's worth to note the reaction proceeded well in the presence of $5 \mathrm{~mol} \% \mathrm{HBF}_{4} . \mathrm{O}(\mathrm{Me})_{2}$ with $(92 \%$ yield, entry 12$)$ or without (75\% yield, entry 13$)$ coppersilver salts.

A similar screening was carried out with cyclohexene (Table 7). The hydroamination reaction of cyclohexene with tosylamine catalysed by a combination of copper(I) bromide and $\mathrm{AgSbF}_{6}$ was also stopped by the addition of an inorganic or organic base (entry 2-4). Addition of calcium hydride (entry 6) scavenged some protons and reduced the reaction yield to $32 \%$. The use of a proton source like hydroquinone (entry 8 ) decreased the reaction yield to $23 \%$. TEMPO (entry 5), benzoquinone (entry 10 ) and $\mathrm{PhSi}(\mathrm{Me})_{3}$ (entry 11) inhibited the reaction. The reaction proceeded well in presence of $5 \mathrm{~mol} \%$

$\mathrm{HBF}_{4} \mathrm{O}(\mathrm{Me})_{2}$ with (90\% yield, entry 12$)$ and without copper-silver salts (50\% yield, entry 13 ). Hence, it was very likely some Brønstedt acid was formed during the hydroamination reaction, by coordination of the nitrogen substrate to the cationic copper(II) or copper(I) complex followed by the release of a proton and formation of a metal- amido complex (Scheme 3). That confirmed a hypothesis which was previously advanced for other hydroamination reactions performed in the presence of a Brønstedt acid source ${ }^{[3 \mathrm{c}, 3 \mathrm{~g}, 6 \mathrm{cc}, 6 \mathrm{~d}, 12]}$.

For intermolecular hydroamination reactions, two pathways can thus be reasonably considered after the olefin protonation (Scheme 3). Pathway 1 would allow the addition of the free amine to the protonated olefin and release of the acid catalyst, the amido-copper complex being an unactive specie. Pathway 2 would allow the amine from copper complex II to react with the protonated olefin releasing the hydroamination product and the dicationic copper complex I.

To check such hypotheses, we performed control experiments. By reacting complex I with tosylamine, complex 6 was isolated and used as catalyst for the reaction of norbornene with tosylamine in dichloromethane at room temperature (Scheme 4).

Scheme 4. Influence of acid amount on the reaction of norbornene with tosylamine.

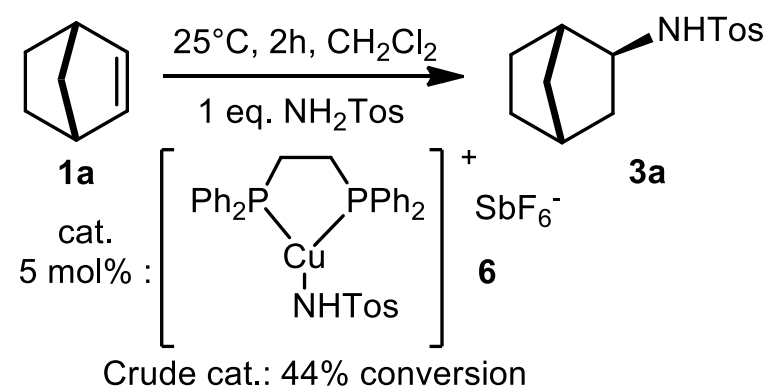

1 time recrystallized cat.: $15 \%$ conversion 2 times recrystallized cat.: $0 \%$ conversion 
When a crude batch of $\mathbf{6}$ was used, a $40 \%$ conversion was obtained. Repeated recrystallizations of $\mathbf{6}$ led to complete deactivation of the catalyst without any decomposition.

In a second control experiment, norbornene reacted with para-nitroaniline using two types of catalysts (Scheme 5).

Scheme 5. Comparison of catalytic activities of in-situ generated and isolated $\mathrm{Cu}(\mathrm{I})$ catalysts.

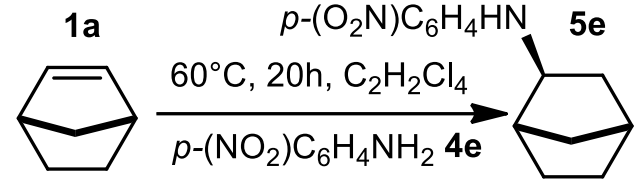

$$
\begin{aligned}
& {\left[5 \mathrm{~mol} \% \mathrm{CuBr}+5 \mathrm{~mol} \% \mathrm{dppe}+5 \mathrm{~mol} \% \mathrm{AgSbF}_{6}\right] \text { : }} \\
& 90 \% \text { conversion } \\
& \text { or } 5 \mathrm{~mol} \%\left[(\mathrm{IPr}) \mathrm{CuNH}_{2} \mathrm{C}_{6} \mathrm{H}_{4}-p-\left(\mathrm{NO}_{2}\right)\right] \mathrm{SbF}_{6} 7 \text { : } \\
& 0 \% \text { conversion }
\end{aligned}
$$

Whereas the hydroamination reaction proceeded well using a one-pot combination of $\mathrm{CuBr}-\mathrm{AgSbF}_{6}-$ dppe, the use of isolated NHC-Cu(I) complex 7 was not successful. Hence, the involvement of such amino- ${ }^{[13 a]}$ or amido- ${ }^{[25]}$ copper complex as a catalyst was unlikely. Moreover, the reaction of norbornene with 4-nitroaniline worked fine when catalysed by a combination of $\mathrm{CuBr}_{2}-\mathrm{AgBF}_{4}$-dppe or simply by $\mathrm{HBF}_{4}$. For both catalysts, rates of conversion were quite similar when followed by NMR and GC (see supporting informations). Hence, according to all these observations, these intermolecular hydroamination reactions may proceed following pathway 1 (Scheme 3 ), Brønstedt acid catalyst being formed when the amine coordinates to the copper cationic complex.

In addition, though the screening of various enantiopure phosphane ligands, no enantioselectivity was obtained for the addition of tosylamine to norbornene (see supporting informations). Obviously, these catalyses were not likely to allow any asymmetric induction as far as they involved the protonation of the olefin before the nucleophile addition of the nitrogen substrate.

For intramolecular hydroamination reactions (Table 8), the catalysis proceeded only for electron rich amine substrates substituted by a benzyl $(\mathbf{8 b}$, entries 3-4,6), a methyl (8c, entries 7-10), an isobutyl (8d, entries 11-14) and a methylcyclohexane (8e, entries 15-16). Reactions required long heating (20-30h) at high temperatures (130$\left.150^{\circ} \mathrm{C}\right)$. No reactivity was observed for a primary amine derivative (8a, entries 1-2) as well as for amides, e.g. electron-poor substrates like tosyl(entries 17-18), acetyl- (entries 19-20), benzoyl- (entries 21-22) and benzylcarbamate derivatives (entries 23-24). Acid catalysis using $\mathrm{HBF}_{4} \cdot \mathrm{O}(\mathrm{Me})_{2}$ improved conversions with benzyl ( $\mathbf{8 b}$, entry 5 ) and isobutyl derivatives (8d, entry 13). Previously, intramolecular hydroamination reactions were reported to proceed efficiently with Brønstedt acid catalysts for amides ${ }^{[\mathrm{gg}, \mathrm{i}, \mathrm{l}, \mathrm{o}, \mathrm{p}]}$ or basic amines ${ }^{[6 \mathrm{c}, \mathrm{d}]}$, metal catalysts being also effective for various substrates ${ }^{[1]}$. In comparison to Ackermann et all. work $^{[6 c, d]}$, our acid-catalysed reactions for compound $\mathbf{8 b}$ (entries 3-6) gave quite similar results at lower catalyst loading (5 against 10-20 mol\%) but at higher temperature (150 against 80$130^{\circ} \mathrm{C}$ ). The reactivity of electron-rich substrates confirmed that an acid-catalysed pathway is likely to take place during intramolecular hydroamination reactions (Scheme 6).

Scheme 6. Proposed mechanism for intramolecular hydroamination reactions.

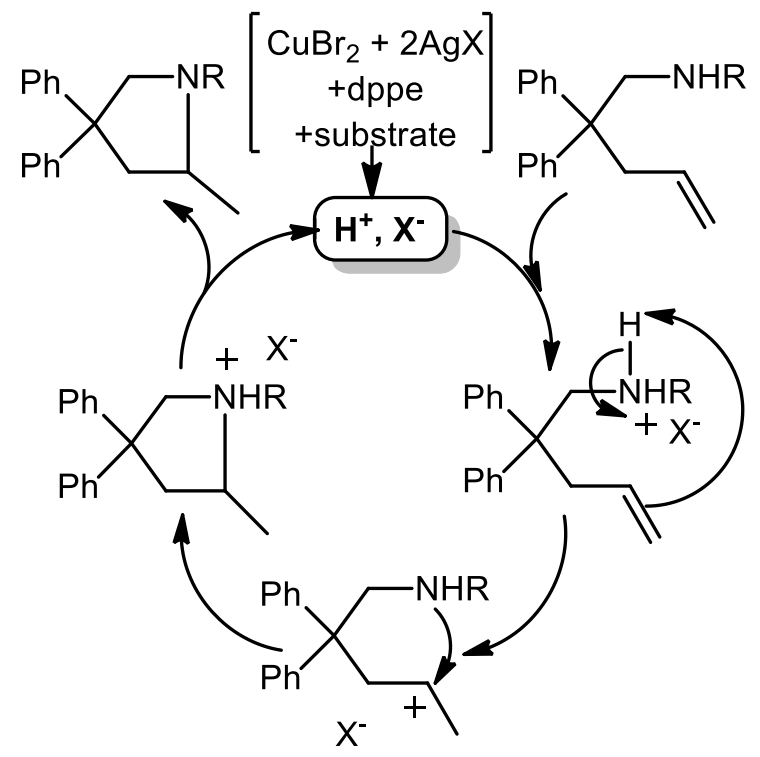

Coordination of the nitrogen substrate to cationic $\mathrm{Cu}$ (II) complex would liberate inorganic acid. Amine would be then protonated; and a protonexchange with the olefin would operate allowing the cyclization to occur and the proton to be released.

Attempts to isolate intermediates were difficult regarding the sensitivity to air and moisture of these $\mathrm{Cu}$ complexes. However, diffusion of an equimolar solution of $[\mathrm{dppeCu}]\left[\mathrm{SbF}_{6}\right]_{2}$ and norbornene in dichloromethane with pentane afforded highly sensitive colorless single crystals. $\mathrm{X}$-ray diffraction analysis showed that norbornenedppeCuSbF 6 complex $\mathbf{1 0}^{[26]}$ was formed (Figure 1). To the best of our knowledge, this is the first structure determination of a phosphane-Cu(I)norbornene complex. 
Table 8. Intramolecular reaction screening.

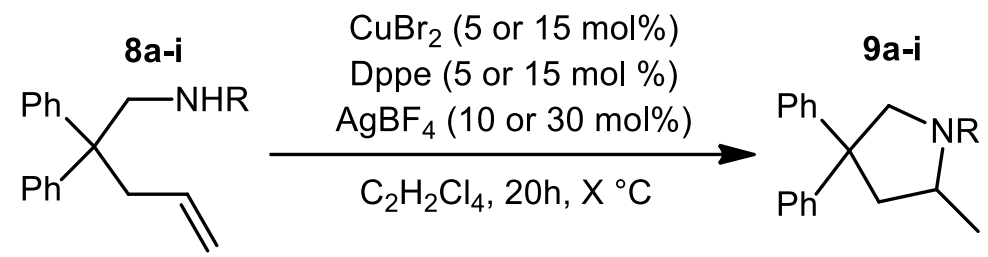

\begin{tabular}{|c|c|c|c|c|}
\hline Entry & $\begin{array}{c}\text { R, } \\
\text { Reagent } 8 \text { a-i }\end{array}$ & Conditions $^{\mathrm{a}}$ & $\begin{array}{c}\text { Temperature } \\
\left({ }^{\circ} \mathrm{C}\right)\end{array}$ & $\begin{array}{c}\text { Conversion }(\%)^{b} \\
\text { [isolated yield \%] } 9 \text { a-i }\end{array}$ \\
\hline 1 & $\mathrm{H}, \mathbf{8 a}$ & A & 100 & 0 \\
\hline 2 & $\mathrm{H}, \mathbf{8 a}$ & $\mathrm{A}$ or $\mathrm{B}$ or $\mathrm{C}$ & 150 & 0 \\
\hline 3 & $\mathrm{Bn}, \mathbf{8 b}$ & A & 100 & 0 \\
\hline 4 & $\mathrm{Bn}, \mathbf{8 b}$ & A & 150 & 79 \\
\hline 5 & $\mathrm{Bn}, \mathbf{8 b}$ & $\mathrm{D}$ & 150 & 91 \\
\hline 6 & $\mathrm{Bn}, \mathbf{8 b}$ & $\mathrm{A}$ & 150 & $100^{c}[85]$ \\
\hline 7 & $\mathrm{Me}, \mathbf{8 c}$ & A & 100 & 0 \\
\hline 8 & $\mathrm{Me}, \mathbf{8 c}$ & A & 130 & 40 \\
\hline 9 & $\mathrm{Me}, \mathbf{8 c}$ & A & 150 & 80 \\
\hline 10 & $\mathrm{Me}^{\mathrm{c}}, \mathbf{8 c}$ & A & 150 & $100^{c}[89]$ \\
\hline 11 & $i-\mathrm{Bu}, \mathbf{8 d}$ & A & 100 & 10 \\
\hline 12 & $i-\mathrm{Bu}, \mathbf{8 d}$ & $\mathrm{A}$ & 130 & 62 \\
\hline 13 & $i-\mathrm{Bu}, \mathbf{8 d}$ & $\mathrm{D}$ & 130 & 82 \\
\hline 14 & $i-\mathrm{Bu}, \mathbf{8 d}$ & $\mathrm{A}$ & 150 & 100 [93] \\
\hline 15 & $\mathrm{CH}_{2} \mathrm{Cy}, \mathbf{8 e}$ & A & 130 & 41 \\
\hline 16 & $\mathrm{CH}_{2} \mathrm{Cy}, \mathbf{8 e}$ & A & 150 & 100 [94] \\
\hline 17 & Ts, $\mathbf{8 f}$ & A & 100 & 0 \\
\hline 18 & Ts, 8f & $\mathrm{A}$ & 150 & 0 \\
\hline 19 & Ac, $\mathbf{8 g}$ & $\mathrm{A}$ & 100 & 0 \\
\hline 20 & Ac, $\mathbf{8 g}$ & $\mathrm{B}$ or $\mathrm{C}$ & 150 & 0 \\
\hline 21 & $\mathrm{Bz}, \mathbf{8 h}$ & A & 100 & 0 \\
\hline 22 & $\mathrm{Bz}, \mathbf{8 h}$ & B & 150 & 0 \\
\hline 23 & $\mathrm{CBz}, \mathbf{8 i}$ & $\mathrm{A}$ & 100 & 0 \\
\hline 24 & $\mathrm{CBz}, \mathbf{8 i}$ & B & 150 & 0 \\
\hline
\end{tabular}

a) Conditions A: 5 mol\% $\mathrm{CuBr}_{2}, 5 \mathrm{~mol} \%$ Dppe, 10 mol\% $\mathrm{AgBF}_{4}$. Conditions B: $15 \mathrm{~mol} \% \mathrm{CuBr}_{2}, 15$ mol\% Dppe, 30 mol\% $\mathrm{AgBF}_{4}$. Conditions C: 5 mol\% $\mathrm{CuBr}_{2}, 5 \mathrm{~mol} \%$ Dppe, $10 \mathrm{~mol} \% \mathrm{AgSbF}_{6}$. Conditions D: 5 mol\% $\mathrm{HBF}_{4} . \mathrm{O}(\mathrm{Me})_{2}$

b) Average of 2 runs. Measured by ${ }^{1} \mathrm{H}$ NMR with 1,3,5-(MeO) ${ }_{3} \mathrm{C}_{6} \mathrm{H}_{3}$ as internal standard.

c) $30 \mathrm{~h}$ reaction.

As demonstrated previously by $\mathrm{EPR}^{[24 \mathrm{~b}]}$, the present $\mathrm{X}$-ray diffraction analysis confirmed that norbornene could reduce copper(II) to copper(I), standard reduction potential of $\left(\mathrm{Cu}^{2+} / \mathrm{Cu}^{+}\right)$being low $\left(E^{0}=\right.$ $+0.159 \mathrm{~V})$. The $\mathrm{C}=\mathrm{C}$ double bond $\mathrm{C} 3-\mathrm{C} 8$ was lengthened $[1.375(5) \AA]$ as compared to the free norbornene $^{[27 \mathrm{a}]}[1.334(1) \AA]$ suggesting $\pi$-back donation from the metal to the olefin. Compound $\mathbf{1 0}$ showed a weak $\mathrm{Cu}$-olefin interaction as confirmed by the large bond distances $\mathrm{Cu}-\mathrm{P} 1$ and $\mathrm{Cu}-\mathrm{P} 2$ [2.2876(8) and 2.2834(8)], as well as by the large bite angle P1$\mathrm{Cu}-\mathrm{P} 2\left[90.71(3)^{\circ}\right]$, values of c.a. $78^{\circ}$ being usually found for stable copper-olefin complexes with nitrogen ligands ${ }^{[27 b-f]}$. This may explain the high instability of compound $\mathbf{1 0}$ which decomposed readily during all other isolation and characterization attempts.

Otherwise, the diffusion of an equimolar solution of $[\mathrm{dppeCu}]\left[\mathrm{SbF}_{6}\right]_{2}$ and tosylamine in dichloromethane with pentane afforded colorless single crystals. X-ray diffraction analysis showed no amido-copper species but a $\mathrm{Cu}(\mathrm{dppe})_{2} \mathrm{SbF}_{6}$ complex $\mathbf{1 1}^{[26]}$ (Figure 2). Similar complexes with different anions ${ }^{[28]}$ were already characterized by X-ray determination and compound 11 exhibited the same structural properties. First, this result confirmed the propensity of copper(II) to be reduced to copper(I) by diphenylphosphinoethane or tosylamine. Second, as previously shown with such phosphane ligands, copper behaves often as a hemilabile metal changing 
easily its coordination ${ }^{[29]}$ unless bonded to strong $\sigma$ donor ligands ${ }^{[25]}$. Hence, several copper organometallics may be formed and stay in equilibrium leading to potent catalytic species.

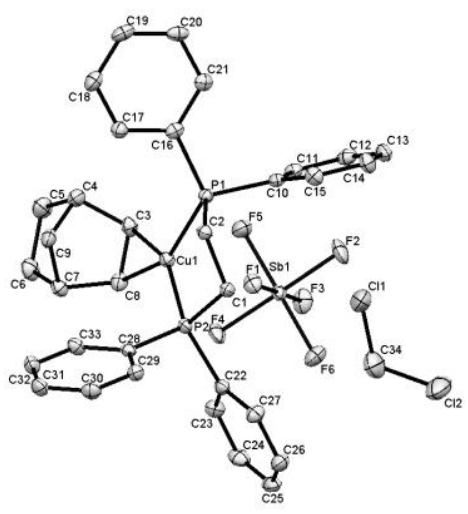

Figure 1. Compound 10 [dppeCuNorbornene] $\mathrm{SbF}_{6} \mathrm{CH}_{2} \mathrm{Cl}_{2}$. Thermal ellipsoids are shown at 50\% level and hydrogen atoms are omitted for clarity ${ }^{27}$. Selected bond length $(\AA)$ and angles ( ${ }^{\circ}$ ): $\mathrm{Cu}-\mathrm{C} 3$ 2.097(3), $\mathrm{Cu}-\mathrm{C} 8$ 2.108(3), Cu-P1 2.2876(8), Cu-P2 2.2834(8), C3-C8 1.375(5), P1-Cu-P2 90.71(3), C3-Cu-C8 38.18(13), P1-P2-C3-C8 0.63(5), P1C2-C1-P2 60.2(2).
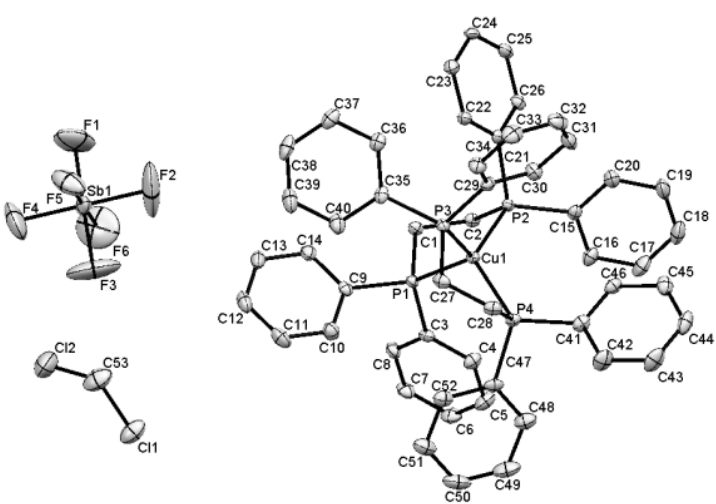

Figure 2. Compound 11 [(dppe $\left.)_{2} \mathrm{Cu}\right] \mathrm{SbF}_{6} \mathrm{CH}_{2} \mathrm{Cl}_{2}$. Thermal ellipsoids are shown at $50 \%$ level and hydrogen atoms are omitted for clarity ${ }^{27}$. Selected bond length $(\AA)$ and angles $\left({ }^{\circ}\right)$ : Cu-P1 2.2906(8), Cu-P2 2.2902(8), Cu-P3 2.2863(8), Cu-P4 2.2940(8), P1-Cu-P2 89.22(3), P1-Cu-P3 115.83(3), P2-Cu-P3 120.65(3), P3-Cu-P4 88.63(3), CuP1-C1-C2 49.06(19), P1-C1-C2-P2 59.0(2), C1-C2-P2-Cu 39.0(2), Cu-P3-C27-C28 48.6(2), P3-C27-C28-P4 49.6(3), $\mathrm{C} 27-\mathrm{C} 28-\mathrm{P} 4-\mathrm{Cu} 25.7(2)$.

\section{Conclusion}

The combined use of copper halides, phosphine ligands and silver salts was applied in the hydroamination of alkenes. Intermolecular reactions of unactivated olefins and nitrogen compounds of moderate nucleophilicity were carried out successfully. Mechanistic investigations demonstrated that the coordination of the amine to the copper cationic complex was generating a Brønsted acid which was the prominent catalytic species. Intramolecular reactions of electron-rich amine derivatives were most likely following an acidcatalysed pathway too. Hence, when a copper halide in combination with a silver salt and a phosphane ligand catalyse the additions of weakly basic amine substrates to olefins, it may be asked whether a true metal-catalysed process is involved or if the metal simply generates a Brønsted acid.

\section{Experimental Section}

\section{General remarks.}

All solvents were dried using standard methods. Alkenes were distilled under vacuum over $\mathrm{CaH}_{2}$ and stored over molecular sieves (4 $\AA$ ). Norbornene was sublimated under vacuum and stored in a glovebox. Amine substrates were placed under vacuum during one hour before use, or distilled over $\mathrm{CaH}_{2}$ if they were liquid. All silver salts, copper salts and ligands were weighted in a glovebox. All reactions were carried out under a dry nitrogen atmosphere. Analytical thin layer chromatography (TLC) was performed on Merck pre-coated $0.20 \mathrm{~mm}$ silica gel Alugram Sil 60 G/UV ${ }_{254}$ plates. Flash chromatography was carried out with Macherey silica gel $60 \mathrm{M} .{ }^{1} \mathrm{H}(300 \mathrm{MHz})$, ${ }^{13} \mathrm{C}(75 \mathrm{MHz})$ and ${ }^{31} \mathrm{P}(121 \mathrm{MHz}) \mathrm{NMR}$ spectra were acquired on a Bruker Avance spectrometer. Chemical shifts are reported downfield of $\mathrm{Me}_{4} \mathrm{Si}$ and coupling constants are expressed in Hz. 1,3,5-trimethoxybenzene and 1,2,4,5-tetrachlorobenzene were used as internal standards when needed. Gas chromatography analyses were done on GC Varian 3900 and 430 using Alltech EconoCap EC- $5^{\mathrm{TM}} 30 \mathrm{~m}$ column with program $\left(5^{\circ} \mathrm{C} / \mathrm{min}\right.$, $100-230^{\circ} \mathrm{C}, 36 \mathrm{~min}$.) and with tetradecane as internal standard. Infrared spectra were recorded on a ThermoScientific-Nicolet 6700 spectrometer; the samples being prepared with $\mathrm{KBr}$ powder. HPLC analysis was performed on a Thermo-Finnigan 1000 apparatus with a diode array detector. HRMS analyses were performed at CUMA-Pharm. Dept.-University Lille Nord de-France. Elemental analyses on sensitive samples were performed at London Metropolitan University, UK. Elemental analyses on other samples were performed at UCCS, University Lille Nord de France, France. See supporting information for other details.

\section{General procedure (olefin reactivities)}

To a Schlenk flask was added $1 \mathrm{mmol}$ of toluenesulfonamide, $0.05 \mathrm{mmol}$ of $\mathrm{CuBr}_{2}$ (or $\mathrm{CuBr}$ ), 0.1 $\mathrm{mmol}$ of $\mathrm{AgSbF}_{6}$ in case of $\mathrm{CuBr}_{2}$ (or $0.05 \mathrm{mmol}$ of $\mathrm{AgSbF}_{6}$ in case of $\mathrm{CuBr}$ ), and $0.05 \mathrm{mmol}$ of 1,2bis(diphenylphosphino)ethane in a glovebox. Then $1.5 \mathrm{~mL}$ of 1,1',2,2'-tetrachloroethane and $4 \mathrm{mmol}$ of the corresponding alkene were added under nitrogen atmosphere. After stirring at 100 or $150^{\circ} \mathrm{C}$, the mixture was filtered over Celite ${ }^{\mathrm{TM}}$, and the corresponding product was isolated by flash chromatography.

\section{General procedure (amine reactivities)}

In a Schlenk flask, $1 \mathrm{mmol}$ of the corresponding amine was dried one hour under vacuum (except aniline which was added at the end of the procedure). Then, $1 \mathrm{mmol}$ of 
norbornene, $0.05 \mathrm{mmol}$ of $\mathrm{CuBr}_{2}, 0.1 \mathrm{mmol}$ of $\mathrm{AgSbF}_{6}$, and $0.05 \mathrm{mmol}$ of 1,2-bis(diphenylphosphino)ethane were added in a glovebox. $1.5 \mathrm{~mL}$ of $1,1^{\prime}, 2,2^{\prime}$ '-tetrachloroethane was added under nitrogen atmosphere. After stirring at $100^{\circ} \mathrm{C}$, the mixture was filtered over Celite ${ }^{\mathrm{TM}}$, and the corresponding product was isolated by flash chromatography.

\section{$\boldsymbol{N}$-1-phenylpropan-2-yl-p-toluenesulfonamide $3 \mathrm{e}$.} Isolated after flash chromatography (petroleum ether:ethylacetate $8: 2, \mathrm{Rf}=0.1$ ) as a colourless oil (from 1 mmol, $0.87 \mathrm{mmol}-252 \mathrm{mg}, 88 \%$ yield $).{ }^{1} \mathrm{H} \mathrm{NMR}\left(\mathrm{CDCl}_{3}\right)$ $\delta 1.10(d, J=6.5,3 \mathrm{H}), 2.43(s, 3 \mathrm{H}), 2.69(d d, J=4.5,2 \mathrm{H})$, $3.53(\operatorname{sep}, J=6.5,1 \mathrm{H}), 4.58(d, J=6.5,1 \mathrm{H}), 7.04(d, J=$ 8.0, 2H), $7.24(m, 5 \mathrm{H}), 7.64(d, J=8.0,2 \mathrm{H}) ;{ }^{13} \mathrm{C} \mathrm{NMR}$ $\left(\mathrm{CDCl}_{3}\right) \delta 21.3\left(\mathrm{CH}_{3}\right), 21.5\left(\mathrm{CH}_{3}\right), 43.4\left(\mathrm{CH}_{2}\right), 50.9(\mathrm{CH})$, $126.6(\mathrm{CH}), 127.0(2 \mathrm{CH}), 128.5(2 \mathrm{CH}), 129.4(2 \mathrm{CH})$, $129.6(2 \mathrm{CH}), 137.1(\mathrm{C}), 137.6(\mathrm{C}), 143.1(\mathrm{C})$; IR $v(\mathrm{KBr}$, $\mathrm{cm}^{-1}$ ) 3323, 2965, 2927, 1313, 1157; HMRS (ESI) $\mathrm{m} / \mathrm{z}$ calcd for $\mathrm{C}_{16} \mathrm{H}_{20} \mathrm{O}_{2} \mathrm{NS}, 290.12093\left(\mathrm{MH}^{+}\right)$, found 290.12080 .

\section{$N$-(2-(pyridin-2-yl)ethyl-p-toluenesulfonamide 3 f.}

Isolated after flash chromatography (petroleum ether:ethylacetate $1: 1, \mathrm{Rf}=0.1$ ) as a white solid (from 1 mmol, 0.16 mmol-44 mg, $16 \%$ yield). M.p. $120-122^{\circ} \mathrm{C} ;{ }^{1} \mathrm{H}$ $\operatorname{NMR}\left(\mathrm{CDCl}_{3}\right) \delta: 2.41(s, 3 \mathrm{H}), 2.93(t, J=6.3,2 \mathrm{H}), 3.35(q$, $J=6.3,2 \mathrm{H}), 6.23(t, J=5.7,1 \mathrm{H}), 7.07(d d, J=7.5, J=4.8$, $1 \mathrm{H}), 7.14(t, J=8.3,1 \mathrm{H}), 7.26(d, J=8.2,2 \mathrm{H}), 7.58(t d, J$ $=7.8, J=1.8,1 \mathrm{H}), 7.72(d, J=8.2,2 \mathrm{H}), 8.46(d, J=4.5$, $1 \mathrm{H}) ;{ }^{13} \mathrm{C} \mathrm{NMR}\left(\mathrm{CDCl}_{3}\right) \delta 21.3\left(\mathrm{CH}_{3}\right), 36.3\left(\mathrm{CH}_{2}\right), 42.3$ $\left(\mathrm{CH}_{2}\right), 121.8(\mathrm{CH}), 123.5(\mathrm{CH}), 127.0(2 \mathrm{CH}), 129.7(2 \mathrm{CH})$, $136.8(\mathrm{CH}), 137.1(\mathrm{C}), 143.2(\mathrm{C}), 149.1(\mathrm{CH}), 158.9(\mathrm{C})$; IR $v\left(\mathrm{KBr}, \mathrm{cm}^{-1}\right): 3063,2956,2864,1324,1155$; HMRS (ESI) $\mathrm{m} / \mathrm{z}$ calcd for $\mathrm{C}_{14} \mathrm{H}_{17} \mathrm{O}_{2} \mathrm{~N}_{2} \mathrm{~S}, 277.1005\left(\mathrm{MH}^{+}\right)$, found 277.1003; Anal. calcd (\%) for $\mathrm{C}_{14} \mathrm{H}_{16} \mathrm{O}_{2} \mathrm{~N}_{2} \mathrm{~S}$ : C, 60.85; $\mathrm{H}$, 5.84; N, 10.14; S, 11.60; found: C, 60.90; H, 5.81; N, $10.78 ; \mathrm{S}, 11.13$.

\section{$N$-Bicyclo[2.2.1]hept-2-yl-2-chloroacetamide 5 b.}

Isolated after flash chromatography (petroleum ether:ethylacetate 8:2) as a white solid (from $1 \mathrm{mmol}, 0.72$ mmol-135 mg, $72 \%$ yield). M.p. $123-125^{\circ} \mathrm{C} ;{ }^{1} \mathrm{H}$ NMR $\left(\mathrm{CDCl}_{3}\right) \delta 1.00-1.30(\mathrm{~m}, 5 \mathrm{H}), 1.35-1.55(\mathrm{~m}, 2 \mathrm{H}), 1.85(\mathrm{~m}$, $1 \mathrm{H}), 2.17(m, 1 \mathrm{H}), 2.25(m, 1 \mathrm{H}), 3.66(t d, J=3.5, J=7.8$, $1 \mathrm{H}), 3.95(s, 2 \mathrm{H}), 6.34(s, 1 \mathrm{H}, \mathrm{NH}) ;{ }^{13} \mathrm{C} \mathrm{NMR}\left(\mathrm{CDCl}_{3}\right) \delta$ $26.4\left(\mathrm{CH}_{2}\right), 28.1\left(\mathrm{CH}_{2}\right), 35.6\left(\mathrm{CH}_{2}\right), 35.7(\mathrm{CH}), 40.2\left(\mathrm{CH}_{2}\right.$, C), $42.2(\mathrm{CH}), 42.6\left(\mathrm{CH}_{2}\right), 53.1(\mathrm{CH}), 164.9(\mathrm{CO})$; IR $v$ $\left(\mathrm{KBr}, \mathrm{cm}^{-1}\right)$ 3291, 2870, 1655, 1549; Anal. calcd (\%) for $\mathrm{C}_{9} \mathrm{H}_{14} \mathrm{ClNO}$ : C, 57.60; H, 7.52; N, 7.46; found: C, 57.15; H, $7.21 ; \mathrm{N}, 7.10$.

\footnotetext{
$N$-Bicyclo[2.2.1]hept-2-yl-carbamic acid benzyl ester 5c. Isolated after flash chromatography (petroleum ether:ethylacetate $8: 2, \mathrm{Rf}=0.6$ ) as a white solid (from 1 mmol, 0.80 mmol-195 mg, $80 \%$ yield). M.p.: $148-150^{\circ} \mathrm{C}$; ${ }^{1} \mathrm{H}$ NMR $\left(\mathrm{CDCl}_{3}\right) \delta 1.05-1.40(m, 5 \mathrm{H}), 1.50(m, 2 \mathrm{H}), 1.70-$ $1.85(m, 1 \mathrm{H}), 2.20-2.35(m, 2 \mathrm{H}), 3.50-3.60(m, 1 \mathrm{H}), 4.70(s$, $1 \mathrm{H}, \mathrm{NH}), 5.1\left(s, 2 \mathrm{H}, \mathrm{CH}_{2}\right), 7.30-7.45(m, 5 \mathrm{H}) ;{ }^{13} \mathrm{C} \mathrm{NMR}$ $\left(\mathrm{CDCl}_{3}\right) \delta 26.3\left(\mathrm{CH}_{2}\right), 28.1\left(\mathrm{CH}_{2}\right), 35.3\left(\mathrm{CH}_{2}\right), 35.6(\mathrm{CH})$, $40.4\left(\mathrm{CH}_{2}\right), 42.5(\mathrm{CH}), 54.3(\mathrm{CH}), 66.5\left(\mathrm{CH}_{2}\right), 128.1(2$ $\mathrm{CH}), 128.2(\mathrm{CH}), 128.5(2 \mathrm{CH}), 136.6(\mathrm{C}), 155.6(\mathrm{C})$; IR $v$ $\left(\mathrm{KBr}, \mathrm{cm}^{-1}\right) 3299,2956,2870,1682,1545,1256$; HMRS
}

(ESI) $m / z$ calcd for $\mathrm{C}_{15} \mathrm{H}_{20} \mathrm{O}_{2} \mathrm{~N}, 246.1489\left(\mathrm{MH}^{+}\right)$, found 246.1487; Anal. calcd (\%) for $\mathrm{C}_{15} \mathrm{H}_{19} \mathrm{O}_{2} \mathrm{~N}$ : C, 73.44; $\mathrm{H}$, 7.81; N, 5.71; found: C, 72.91; H, 7.89; N, 5.47.

\section{$N$-Bicyclo[2.2.1]hept-2-yl-2H-benzo[d][1,2,3]triazole $5 f_{1}$} Isolated by flash chromatography (petroleum ether:ethyl acetate 80:20, $\mathrm{Rf}=0.7$ ) as a white solid (from $1 \mathrm{mmol}$, $0.14 \mathrm{mmol}$ (30 mg), $14 \%$ yield). Melting point: $45-47^{\circ} \mathrm{C}$. ${ }^{1} \mathrm{H}$ NMR $\left(300 \mathrm{MHz}, \mathrm{CDCl}_{3}\right) \delta: 1.20-1.80(m, 7 \mathrm{H}), 2.50-$ $2.85(m, 3 \mathrm{H}), 4.88(d d, J=4.2 \mathrm{~Hz}, J=8.5 \mathrm{~Hz}, 1 \mathrm{H}), 7.39$ $(m, 2 \mathrm{H}), 7.89(m, 2 \mathrm{H}) ;{ }^{13} \mathrm{C} \mathrm{NMR}\left(75 \mathrm{MHz}, \mathrm{CDCl}_{3}\right) \delta: 27.1$ $\left(\mathrm{CH}_{2}\right), 28.5\left(\mathrm{CH}_{2}\right), 35.8\left(\mathrm{CH}_{2}\right), 36.1(\mathrm{CH}), 38.2\left(\mathrm{CH}_{2}\right)$, $44.1(\mathrm{CH}), 69.4(\mathrm{CH}), 118.0(2 \mathrm{CH}), 126.0(2 \mathrm{CH}), 143.9$ (2C). IR v: 2955, 2870, $1277 \mathrm{~cm}^{-1}$. HMRS (ESI) calcd for $\mathrm{C}_{13} \mathrm{H}_{16} \mathrm{~N}_{3}, 214.13387\left(\mathrm{MH}^{+}\right)$, found 214.13374; Anal. calcd (\%) for $\mathrm{C}_{13} \mathrm{H}_{15} \mathrm{~N}_{3}$ : C, 73.21; H, 7.09; N, 19.70; found: C, 72.69; H, 7.09; N, 20.34.

\section{$N$-Bicyclo[2.2.1]hept-2-yl-1H-benzo[ $[d][1,2,3]$ triazole $5 f_{2}$} Isolated by flash chromatography (petroleum ether:ethyl acetate 80:20, $\mathrm{Rf}=0.3$ ) as a white solid (from $1 \mathrm{mmol}$, $0.21 \mathrm{mmol}(46 \mathrm{mg}), 21 \%$ yield). Melting point: $75-77^{\circ} \mathrm{C}$. ${ }^{1} \mathrm{H}$ NMR $\left(300 \mathrm{MHz}, \mathrm{CDCl}_{3}\right) \delta: 1.30-2.10(m, 7 \mathrm{H}), 2.50-$ $2.80(m, 3 \mathrm{H}), 4.60(d d, J=3.8 \mathrm{~Hz}, J=8.4 \mathrm{~Hz}, 1 \mathrm{H}), 7.36$ $(m, \mathrm{H}), 7.47(t, \mathrm{H}), 7.56(d, J=8.3 \mathrm{~Hz}, \mathrm{H}), 8.07(d, J=8.3$ $\mathrm{Hz}, \mathrm{H}) ;{ }^{13} \mathrm{C}$ NMR $\left(75 \mathrm{MHz}, \mathrm{CDCl}_{3}\right) \delta: 27.1\left(\mathrm{CH}_{2}\right), 28.7$ $\left(\mathrm{CH}_{2}\right), 35.9\left(\mathrm{CH}_{2}\right), 36.0(\mathrm{CH}), 37.3\left(\mathrm{CH}_{2}\right), 42.9(\mathrm{CH}), 61.9$ $(\mathrm{CH}), 109.7(\mathrm{CH}), 119.9(\mathrm{CH}), 123.8(\mathrm{CH}), 126.8(\mathrm{CH})$, 133.0 (C), 146.3 (C). IR v: 2963, 2868, $1454 \mathrm{~cm}^{-1}$; HMRS (ESI) calcd for $\mathrm{C}_{13} \mathrm{H}_{16} \mathrm{~N}_{3}, 214.13387\left(\mathrm{MH}^{+}\right)$, found 214.1338; Anal. calcd (\%) for $\mathrm{C}_{13} \mathrm{H}_{15} \mathrm{~N}_{3}$ : C, 73.21; H, 7.09; N, 19.70; found: C, 73.64; H, 7.47; N, 20.14.

\section{$N$-Bicyclo[2.2.1]hept-2-yl-oxazolidin-2-one 5g.}

Isolated after flash chromatography (petroleum ether:acetone 7:3, $\mathrm{Rf}=0.6$ ) as colourless oil (from $1 \mathrm{mmol}$, $0.95 \mathrm{mmol}-173 \mathrm{mg}, 95 \%$ yield $).{ }^{1} \mathrm{H}$ NMR $\left(\mathrm{CDCl}_{3}\right) \delta 1.30$ $(m, 4 \mathrm{H}), 1.50(\mathrm{~m}, 3 \mathrm{H}), 1.78(m, 1 \mathrm{H}), 2.25(s, 1 \mathrm{H}), 2.31(s$, $1 \mathrm{H}), 3.55(\mathrm{~m}, 2 \mathrm{H}), 3.78(\mathrm{dd}, J=8, J=5,1 \mathrm{H}), 4.20-4.35(\mathrm{~m}$, $2 \mathrm{H}) ;{ }^{13} \mathrm{C} \mathrm{NMR}\left(\mathrm{CDCl}_{3}\right) \delta 27.7\left(\mathrm{CH}_{2}\right), 28.0\left(\mathrm{CH}_{2}\right), 36.0$ $(\mathrm{CH}), 36.6\left(\mathrm{CH}_{2}\right), 36.7\left(\mathrm{CH}_{2}\right), 40.5(\mathrm{CH}), 42.1\left(\mathrm{CH}_{2}\right), 56.4$ $(\mathrm{CH}), 61.8\left(\mathrm{CH}_{2}\right), 158.2(\mathrm{CO})$; IR $v\left(\mathrm{KBr}, \mathrm{cm}^{-1}\right) 2870$, 1743, 1263; HMRS (ESI) $\mathrm{m} / z$ calcd for $\mathrm{C}_{10} \mathrm{H}_{16} \mathrm{O}_{2} \mathrm{~N}$, 182.1176 $\left(\mathrm{MH}^{+}\right)$, found 182.1177.

\section{[Diphenylphosphinoethano][4-methyl-benzene- sulfonamidato- $\kappa-N$-]copper(I) hexafluoroantimonate: [dppeCuNHTos][SbF 6 ] 6.}

$\mathrm{CuBr}_{2}(0.052 \mathrm{~g}, 0.23 \mathrm{mmol}), 1,2-$

bis(diphenylphosphino)ethane $(0.093 \mathrm{~g}, 0.23 \mathrm{mmol})$ and $\mathrm{AgSbF}_{6}(0.16 \mathrm{mg}, 0.46 \mathrm{mmol})$ were dissolved in $5 \mathrm{~mL}$ dichloromethane. After stirring for 3 hours under nitrogen at room temperature, $\mathrm{AgCl}$ was removed by filtration through Celite ${ }^{\mathrm{TM}}$ under nitrogen and the filtrate was allowed to reacted 20 minutes ( $10 \mathrm{~min}$. ultrasonic bath +10 min. stirring at R.T.) with tosylamine ( $0.04 \mathrm{~g}, 0.23 \mathrm{mmol})$. Evaporation to dryness afforded a grey solid which was recrystallised two times using $\mathrm{CH}_{2} \mathrm{Cl}_{2}$ and pentane then dried affording a white solid (0.08 g, $40 \%$ yield). ${ }^{1} \mathrm{H}$ NMR $\left(\mathrm{CD}_{2} \mathrm{Cl}_{2}\right) \delta: 2.16\left(s, 2 \mathrm{H}, \mathrm{CH}_{2}\right), 2.47(s, 3 \mathrm{H}, \mathrm{Me}), 4.87(s$ broad, $1 \mathrm{H}, \mathrm{NH}), 7.22(m, 2 \mathrm{H}), 7.36\left(d, 2 \mathrm{H},{ }^{3} J=8.1, \mathrm{H}_{T o s}\right)$, $7.48(m, 4 \mathrm{H}), 7.69(m, 4 \mathrm{H}), 7.81\left(d, 2 \mathrm{H},{ }^{3} \mathrm{~J}=8.1, \mathrm{H}_{T o s}\right) ;{ }^{31} \mathrm{P}$ 
$\operatorname{NMR}\left(\mathrm{CD}_{2} \mathrm{Cl}_{2}\right) \delta: 50.04 ;{ }^{13} \mathrm{C} \mathrm{NMR}\left(\mathrm{CD}_{2} \mathrm{Cl}_{2}\right) \delta: 21.2,29.7$, $126.3,129.1,129.6,129.7,130.4,131.0,131.6,132.1(2 \mathrm{C})$, 132.7, 138.9, 143.9; IR $v\left(\mathrm{~cm}^{-1}\right)(\mathrm{KBr}$, inert cell) $3360(\mathrm{~s})$, 3260 (s), 1304 (vs), 1160 (s); Anal. calcd (\%) for $\mathrm{C}_{33} \mathrm{H}_{32} \mathrm{~F}_{6} \mathrm{O}_{2} \mathrm{P}_{2} \mathrm{NSCuSb}: \mathrm{C}, 45.67 ; \mathrm{H}, 3.72 ; \mathrm{N}, 1.61$; found: $\mathrm{C}, 45.44 ; \mathrm{H}, 3.61 ; \mathrm{N}, 1.75$.

\section{[1,3-bis(2,6-di-i-propyl-phenyl)imidazol-2-ylidene][4- nitroaniline- $\kappa-N$-]copper(I) hexafluoroantimonate: $\left[(\mathrm{IPr}) \mathrm{Cu}\left(\mathrm{NH}_{2} \mathrm{C}_{6} \mathrm{H}_{4} \mathrm{NO}_{2}\right)\right]\left[\mathrm{SbF}_{6}\right] 7$.}

$(\mathrm{IPr}) \mathrm{CuCl}(0.05 \mathrm{~g}, 0.1 \mathrm{mmol})$ was combined with $\mathrm{AgSbF}_{6}$ $(0.036 \mathrm{~g}, 0.1 \mathrm{mmol})$ in $4 \mathrm{ml} \mathrm{THF}$. After stirring for 1 hour, $\mathrm{AgCl}$ was removed by filtration through dry Celite ${ }^{\mathrm{TM}}$, and the filtrate was concentrated in vacuo to approximately 2 $\mathrm{mL}$ and transferred to a $4 \mathrm{~mL}$ THF solution of 4nitroaniline $(0.014 \mathrm{~g}, 0.1 \mathrm{mmol})$. The resulting solution was heated to $60^{\circ} \mathrm{C}$ under nitrogen for one hour. Evaporation to dryness afforded a yellow solid $(0.074 \mathrm{~g}$, $90 \%$ yield $).{ }^{1} \mathrm{H}$ NMR $\left(\mathrm{CD}_{2} \mathrm{Cl}_{2}\right) \delta: 1.17\left(d,{ }^{3} \mathrm{~J}=7.0,12 \mathrm{H}\right.$, $\left.\mathrm{CH}\left(\mathrm{CH}_{3}\right)_{2}\right), 1.24\left(d,{ }^{3} \mathrm{~J}=7.0,12 \mathrm{H}, \mathrm{CH}\left(\mathrm{CH}_{3}\right)_{2}\right), 2.47$ (sept, $\left.{ }^{3} J=7.9,4 \mathrm{H}, \mathrm{CH}\left(\mathrm{CH}_{3}\right)_{2}\right), 5.08\left(s, 2 \mathrm{H}, \mathrm{NH} H_{2}\right), 6.70\left(d,{ }^{3} \mathrm{~J}=\right.$ 9.2, 2H, CH 4-nitroaniline); $7.32(m, 6 \mathrm{H}, \mathrm{NCH}+\mathrm{CH} \mathrm{IPr}$ $p$-phenyl); $7.57\left(t,{ }^{3} J=7.7,2 \mathrm{H}\right), 7.99\left(d,{ }^{3} J=9.2,2 \mathrm{H}, \mathrm{CH}\right.$ 4-nitroaniline); ${ }^{13} \mathrm{C}$ NMR $\left(\mathrm{CD}_{2} \mathrm{Cl}_{2}\right) \delta: 176.5(\mathrm{NCN}), 145.5$, 144.3, 133.9, 130.9, 125.7, 124.4(2C), 124.2, 120.1, 29.7 $\left(\mathrm{CH}\left(\mathrm{CH}_{3}\right)_{2}\right)$, $24.6\left(\mathrm{CH}\left(\mathrm{CH}_{3}\right)_{2}\right), 23.6\left(\mathrm{CH}\left(\mathrm{CH}_{3}\right)_{2}\right)$; Anal. calcd (\%) for $\mathrm{C}_{33} \mathrm{H}_{43} \mathrm{~F}_{6} \mathrm{~N}_{4} \mathrm{O}_{2} \mathrm{CuSb}: \mathrm{C}, 47.93 ; \mathrm{H}, 5.24 ; \mathrm{N}$, 6.77; found: C, 47.81; H, 5.11; N, 6.65.

\section{Bis[bis(diphenylphosphino)ethano]copper(I) hexafluoroantimonate:[(dppe $\left.)_{2} \mathrm{Cu}\right]\left[\mathrm{SbF}_{6}\right] \mathbf{1 1}$.} $\mathrm{CuBr}(0.067 \mathrm{~g}, 0.47 \mathrm{mmol})$, diphenylphosphinoethane (0.37 g, $0.94 \mathrm{mmol})$ and $\mathrm{AgSbF}_{6}(161 \mathrm{mg}, 0.47 \mathrm{mmol})$ were dissolved in $5 \mathrm{~mL}$ dichloromethane. After stirring for 3 hours under nitrogen at room temperature, $\mathrm{AgCl}$ was removed by filtration through dry Celite ${ }^{\mathrm{TM}}$ under nitrogen and the filtrate was evaporated to dryness to afford a white solid $(0.486 \mathrm{~g}, 95 \%$ yield $) .{ }^{1} \mathrm{H}$ NMR $\left(\mathrm{CD}_{2} \mathrm{Cl}_{2}\right) \delta: 2.48(m$, $\left.8 \mathrm{H}, \mathrm{CH}_{2}\right), 7.25\left(m, 29 \mathrm{H}, \mathrm{H}_{A r}\right), 7.41\left(\mathrm{~m}, 10 \mathrm{H}, \mathrm{H}_{A r}\right) ;{ }^{31} \mathrm{P}$ NMR $\left(\mathrm{CD}_{2} \mathrm{Cl}_{2}\right) \delta$ : 7.24 (very broad singlet), $4.17(\mathrm{~d}, J=$ 17.8), $2.11(\mathrm{~d}, J=17.7)$; Anal. calcd (\%) for $\mathrm{C}_{52} \mathrm{H}_{48} \mathrm{~F}_{6} \mathrm{P}_{4} \mathrm{CuSb}: \mathrm{C}, 56.98 ; \mathrm{H}, 4.41$; found: $\mathrm{C}, 56.90 ; \mathrm{H}$, 4.30 .

\section{Acknowledgements}

This work is first financed by the French National Research Agency with project ANR-09-BLAN-0032-02 (with a PhD fellowship to F.M). Support from CNRS is warmly acknowledged. Partial funding from Région Nord-Pas de Calais with "Projet Prim: Etat-Région" is also appreciated. Dr I. Suisse is thanked for preliminary experiments. Mrs C. Méliet is thanked for elemental analyses on organic samples. The authors are grateful to reviewers for their comments.

\section{References}

[1] a) J. J. Brunet, D. Neibecker in Catalytic Heterofunctionalization from Hydroamination to Hydrozirconation, (Eds.: A. Togni and $\mathrm{H}$. Grutzmacher), Wiley-VCH, Weinheim, Germany, 2001, pp. 10-20 ; b) S. Doye in Science of Synthesis, Vol. 40a,
(Eds.: D. Enders, E. Schaumann), Thieme, Stuttgart, 2009, pp. 241-304 ; c) U. M. Dzhemilev, G.A. Tolstikov, R. I. Khusnutdinov, Russ. J. Org. Chem. 2009, 45, 957-987 ; d) T. E. Mueller, K. C. Hultzsch, M. Yus, F. Foubelo, M. Tada, Chem. Rev. 2008, 108, 3795-3892 ; e) I. Aillaud, J. Collin, J. Hannedouche, E. Schulz, Dalton Trans. 2007, 5105-5118 ; f) K. C. Hultzsch, Adv. Synth. Catal. 2005, 347, 367-391 ; g) A. L. Odom, Dalton Trans. 2005, 225-233 ; h) I.

Bytschkov, S. Doye, Eur. J. Org. Chem. 2003, 935946 ; i) P. W. Roesky, T. E. Müller, Angew. Chem. 2003, 115, 2812-2814; Angew. Chem. Int. Ed. 2003, 42, 2708-2710 ; j) T. E. Müller, M. Beller, Chem. Rev. 1998, 98, 675-703.

[2] a) J. Guin, R. Fröhlich, A. Studer, Angew Chem. 2008, 120, 791-794 ; Angew. Chem. Int. Ed. 2008, 47, 779782 ; b) J. Guin, C. Mück-Lichtenfeld, S. Grimme, A. Studer, J. Am. Chem. Soc. 2007, 129, 4498-4503.

[3] For selected examples of metal-acid catalysed hydroamination of alkenes: a) H. Kitahara, H. Sakurai, Chem. Lett. 2010, 39, 46-48 ; b) P. A. Dub, M. Rodrigues-Zubiri, C. Baudequin, R. Poli, Green Chem. 2010, 12, 1392-1396 ; c) J. L. McBee, A. T. Bell, T. D. Tilley, J. Am. Chem. Soc. 2008, 130, 16562-16571 ; d) C. F. Bender, R. A. Widenhoefer, Chem. Commun. 2008, 2741-2743 ; e) B. M. Cochran, F. E. Michael, J. Am. Chem. Soc. 2008, 130, 2786-2792 ; f) W. J. Shi, Y. Liu, P. Butti, A. Togni, Adv. Synth. Catal. 2007, 349, 1619-1623 ; g) L. T. Kaspar, B. Fingerhut, L. Ackermann, Angew Chem. 2005, 117, 6126-6128 ; Angew. Chem. Int. Ed. 2005, 44, 5972-5974 ; h) D. Karshtedt, A. T. Bell, T. D. Tilley, J. Am. Chem. Soc. 2005, 127, 12640-12646 ; i) L. Ackermann, L. T. Kaspar, C. J. Gschrei, Org. Lett. 2004, 6, 2515-2518 ; j) T. C. Wabnitz, J. Q. Yu, J. B. Spencer Chem. Eur. J. 2004, 10, 484-493 ; k) L. L. Anderson, J. Arnold, R. G. Bergman, Org. Lett. 2004, 6, 2519-2522 ; 1) J. Penzien, R. Q. Su, T. E. Müller, J. Mol. Catal. A Chem. 2002, 182-183, 489-498 ; m) R. Q. Su, T. E. Müller, Tetrahedron 2001, 57, 6027-6033 ; n) M. Kawatsura, J. F. Hartwig, J. Am. Chem. Soc. 2000, 126, 9546-9547 ; o) M. Beller, O. R. Thiel, H. Trauthwein, Synlett 1999, 243-244 ; p) M. Al-Masum, M. Meguro, Y. Yamamoto, Tetrahedron Lett. 1997, 28, 6071-6074 ; q) M. Beller, H. Trauthwein, M. Eichberger, C. Breindl, J. Herwig, T. E. Müller, O. R. Thiel, Chem. Eur. J. 1999, 5, 13061319 ; r) J. J. Brunet, D. Commenges, D. Neibecker, K. Philippot, J. Organomet. Chem. 1994, 469, 221-228 ; s) J. Ambühl, P. S. Pregosin, L. M. Venanzi, G. Ughetto, L. Zambonelli, J. Organomet. Chem. 1978, 160, 329335 .

[4] For selected examples of Lewis acid catalysed hydroamination of alkenes: a) Ga: D. Jaspers; R. Kubiak, S. Doye, Synlett 2010, 1268-1272 ; b) Bi: N. Kawai, R. Abe, J; Uenishi, Tetrahedron Lett. 2009, 50, 6580-6583 ; c) Zr: L. Yang, L. W. Xu, W. Zhou, Y. H. Gao, W. Sun, C. G. Xia, Synlett 2009, 1167-1171 ; d) X. Cheng, Y. Xia, H. Wei, B. Xu, C. Zhang, Y. Li, G. Qian, X. Zhang, K. Li, W. Li, Eur. J. Org. Chem. 2008, 1929-1936 ; e) Bi : H. Wei, Q. Gumin, Y. Xia, K. Li, Y. Li, W. Li, Eur. J. Org. Chem. 2007, 4471-4474 ; f) Bi, 
Hf: H. Qin, N. Yamagiwa, S. Matsunaga, M. Shibasaki, Chem. Asian. J. 2007, 2, 150-154 ; g) In: J. M. Huang, C. M. Wong, F. X. Xu, T. P. Loh, Tetrahedron Lett. 2007, 48, 3375-3377 ; h) Fe: J. Michaux, V. Terrasson, S. Marque, J. Wehbe, D. Prim, J. M. Campagne, Eur. J. Inorg. Chem. 2007, 2601-2603 ; i) Fe: K. Komeyama, T. Morimoto, K. Takaki, Angew Chem. 2006, 118, 3004-3007 ; Angew. Chem. Int. Ed. 2006, 45, 2938 2941 ; j) Bi: H. Qin, N. Yamagiwa, S. Matsunaga, M. Shibasaki, J. Am. Chem. Soc. 2006, 128, 1611-1614.

[5] For selected examples of heterogeneous Brønsted acid hydroamination of alkenes: a) D. P. Sawant, J. Justus, V. V. Balasubramanian, K. Ariga, P. Srinivasu, S. Velmathi, S. B. Halligudi, A. Vinu, Chem. Eur. J. 2008, 14, 3200-3212; b) L. Yang, L. W. Xu, C. G. Xia, Tetrahedron Lett. 2008, 49, 2882-2885 ; c) J. S. Yadav, B. V. S. Reddy, A. Raju, K. Ravindar, R. Narender, Lett. Org. Chem. 2008, 5, 651-654 ; d) G. V. Shanbhag, S. M. Kumbar, S. B. Halligudi, J. Mol. Catal. A Chem 2008, 284, 16-23 ; e) K. Motokura, N. Nakagiri, K. Mori, T. Mizugaki, K. Ebitani, K. Jitsukawa, K. Kaneda, Org. Lett. 2006, 8, 4617-4620; f) O. Jimenez, T. E. Müller, C. Sievers, A. Spirkl, J. A. Lercher, Chem. Commun. 2006, 2974-2976 ; g) M. Lequitte, F. Figueras, C. Moreau, S. Hub, J. Catal. 1996, 163, 255261; h) N. Mizuno, M. Tabata, T. Uematsu, M. Iwamoto, J. Catal. 1994, 146, 249-256; i) M. Deeba, M. E. Ford, T. A. Johnson, Chem. Commun. 1987, 562-563.

[6] For selected examples of homogeneous Brønsted acid hydroamination of alkenes: a) (amides) C. M. GriffithsJones (née Haskins), D. W. Knight, Tetrahedron 2010, 66, 4150-4166 ; b) (amides, anilines) L. Yang, L. W. Xu, C. G. Xia, Synthesis 2009, 1969-1974 ; c) (basic amines) L. Ackermann, A. Althammer, Synlett 2008, 995-998 ; d) (basic amines) L. Ackermann, L. T. Kaspar, A. Althammer, Org. Biomol. Chem. 2007, 5, 1975-1978 ; e) (anilines) K. Márcsekova, S. Doye, Synthesis 2007, 145-154 ; f) (anilines) N. S. Babu, K. M. Reddy, P. S. S. Prasad, I. Suryanarayana, N. Lingaiah, Tetrahedron Lett. 2007, 48, 7642-7645 ; g) (amides) Y. Yin, G. Zhao, J. Fluorine Chem. 2007, 128, 40-45 ; h) (amides) D. C. Rosenfeld, S. Shekhar, A. Takemiya, M. Utsunomiya, J. F. Hartwig, Org. Lett. 2006, 8, 4179-4182 ; i) (amides) Z. Li, J. Zhang, C. Brouwer, C. G. Yang, N. W. Reich, C. He, Org. Lett. 2006, 8, 4175-4178 ; j) (anilines) A. A. M. Lapis, B. A. DaSilveira Neto, J. D. Scholten, F. M. Nachtigall, M. N. Eberlin, J. Dupont, Tetrahedron Lett. 2006, 47, 67756779 ; k) (amides) Y. Yin, G. Zhao, Heterocycles 2006, 68, 23-31 ; 1) (anilines) L. L. Anderson, J. Arnold, R. G. Bergman, J. Am. Chem. Soc. 2005, 127, 14542-14543 and references therein ; m) (anilines) A. E. Cherian, G. J. Domski, J. M. Rose, E. B. Lobokovsky, G. W. Coates, Org. Lett. 2005, 7, 5135-5137 ; n) (amides) C. M. Haskins, D. W. Knight Chem. Commun. 2005, 3162-3164 ; o) (amides) S. K. Talluri, A. Sudalai, Org. Lett. 2005, 7, 855-857 ; p) (amides) P. A. Colinas, R. D. Bravo, Org. Lett. 2003, 5, 4509-4511 ; q) (amides) B. Schlummer, J. F. Hartwig, Org. Lett. 2002, 4, 14711474 ; r) (amides) C. M. Haskins, D. W. Knight, Chem. Commun. 2002, 2724-2725.
[7] a) Z. Zhang, S. D. Lee, R. A. Widenhoefer, J. Am. Chem. Soc., 2009, 131, 5372-5373 ; b) X. Giner, C. Najera, Org. Lett., 2008, 10, 2919-2922 ; c) M. Shi, L. P. Liu, J. Tang, Org. Lett. 2006, 8, 4043-4046 ; d) J. Zhang, C. G. Yang, C. He, J. Am. Chem. Soc. 2006, 128, 1798-1799 ; e) C. Brouwer, C. He, Angew Chem. 2006, 118, 1776-1779; Angew. Chem. Int. Ed. 2006, 45, $5,1744-1747$; f) X. Y. Liu, C. H. Li, C. M. Che, Org. Lett. 2006, 8, 2707-2710 ; g) M. C. P. Yeh, H. F. Pai, Z. J. Lin, B. R. Lee, Tetrahedron 2009, 65, 4789-4794 ; h) H. Kitahara, H. Sakurai, Chem. Lett. 2010, 39, 46-48.

[8] a) R. L. LaLonde, Z. J. Wang, M. Mba, A. D. Lackner, F. D. Toste, Angew Chem. 2010, 122, 608-611; Angew. Chem. Int. Ed. 2010, 49, 598-601; b) K. Aikawa, M. Kojima, K. Mikami, Angew Chem. 2009, 121, 61896193 ; Angew. Chem. Int. Ed. 2009, 48, 6073-6077 ; c) Z. Zhang, C. F. Bender, R. A. Widenhoefer, J. Am. Chem. Soc. 2007, 129, 14148-14149 ; d) G. L. Lalonde, B. D. Sherry, E. J. Kang, F. D. Toste, J. Am. Chem. Soc. 2007, 129, 2452-2453 ; e) N. Nishina, Y. Yamamoto, Angew Chem. 2006, 118, 3292-3295; Angew. Chem. Int. Ed. 2006, 45, 3314-3317 ; f) N. T. Patil, L. M. Lutete, N. Nishina, Y. Yamamoto, Tetrahedron Lett. 2006, 47, 4749-4751.

[9] X. Giner, C. Najera, Synlett 2009, 3211-3213.

[10] a) B. Zhao, H. Du, Y. Shi, J. Org. Chem. 2009, 74, 8392-8395 ; b) H. Du, B. Zhao, W. Yuan, Y. Shi, Org. Lett. 2008, 10, 4231-4234.

[11] a) E. S. Sherman, S. R. Chemler, Adv. Synth. Catal. 2009, 351, 467-471 ; b) W. Zeng, S. R. Chemler, J. Org. Chem. 2008, 73, 6045-6047.

[12] a) J. G. Tayor, L. A. Adrio, K. K. Hii, Dalton Trans. 2010, 39, 1171-1175 ; b) J. G. Taylor, N. Whittall, K. K. Hii, Org. Lett. 2006, 8, 3561-3564.

[13] a) C. Munro-Leighton, S. A. Delp, E. D. Blue, T. B. Gunnoe, Organometallics 2007, 28, 1483-1493 ; b) C. Munro-Leighton, E. D. Blue, T. B. Gunnoe, J. Am. Chem. Soc. 2006, 128, 1446-1447.

[14] H. Ohmiya, T. Moriya, M. Sawamura, Org. Lett. 2009, $11,2145-2147$.

[15] a) J. J. Brunet, D. Neibecker, F. Agbossou, S. S. Radhey, J. Mol. Catal. 1994, 87, 223-230 ; b) J. J. Brunet, D. Neibecker, F. Niedercorn, J. Mol. Catal. 1989, 49, 235-259.

[16] For selected examples of copper-olefin complexes: a) P. O. Oguadinma, F. Schaper, Organometallics 2009, 28, 6721-6731 ; b) J. S. Thompson, A. Z. Bradley, K. H. Park, K. D. Dobbs, W. Marshall, Organometallics 2006, 25, 2712-2714 ; c) G. Pampaloni, R. Peloso, C. Graiff, A. Tiripicchio, Organometallics 2005, 24, 819-825 ; d) W. A. Braunecker, T. Pintauer, N. V. Tsarevsky, G. Kickelbick, K. Matyjaszewski, J. Organomet. Chem. 2005, 690, 916-924 ; e) P. Kamau, R. B. Jordan, Inorg. Chem. 2002, 41, 884-891.

[17] a) R. Dias, J. Wu, Eur. J. Inorg. Chem. 2008, 509522 ; b) J. S. Thompson, R. L. Harlow, J. F. Whitney, J. Am. Chem. Soc. 1983, 105, 3522-3527. 
[18] A. Tsuhako, D. Oikawa, K. Sakai, S. Okamoto, Tetrahedron Lett. 2008, 49, 6529-6532.

[19] a) M. J. S. Dewar, Bull. Soc. Chim. Fr. 1951, 18, C71C79 ; b) J. Chatt, L. A. Duncanson, J. Chem. Soc. 1953, 2939-2947 ; c) C. Hahn, Chem. Eur. J. 2004, 10, 58885899.

[20] a) P. Lazlo, P. v. R. Schleyer J. Am. Chem. Soc. 1964, 86, 1171-1179 ; b) J. E. Franz, C. Osuch, M. W. Dietrich J. Org. Chem. 1964, 29, 2922-2927.

[21] a) C. Q. Zhao, M. C. Jennings, R. J. Puddephat, Inorg. Chim. Acta 2008, 361, 3301-3308 ; b) K. N. Lazarou, S. P. Perlepes, V. Psycharis, C. P. Raptopoulou, Polyhedron 2008, 27, 2131-2142.

[22] a) J. Moran, P. H. Cebrowski, A. M. Beauchemin, J. Org. Chem. 2008, 73, 1004-1007 ; b) A. R. Katritzky, I. B. Puschmann, C. V. Stevens, A. P. Wells, J. Chem. Soc. Perkin Trans. 2 1995, 1645-1649.

[23] For selected examples of hydroaminationhydroarylation of alkynes: a) N. T. Patil, P. G. V. V. Lakshmi, V. Singh, Eur. J. Org. Chem. 2010, 47194731 ; b) Y. Zhou, E. Feng, G. Liu, D. Ye, J. Li, H. Jiang, H. Liu, J. Org. Chem. 2009, 74, 7344-7348 ; c) N. T. Patil, R. D. Kavthe, V. S. Raut, V. V. N. Reddy, J. Org. Chem. 2009, 74, 6315-6318; d) X. Y. Liu, P. Ding, J. S. Huang, C. M. Che, Org. Lett. 2007, 9, 26452648 ; e) N. Pasha, N. S. Babu, K. T. V. Rao, P. S. Prasad, N. Lingaiah, Tetrahedron Lett. 2009, 50, 239242 ; f) R. Severin, S. Doye, Chem. Soc. Rev. 2007, 36, 1407-1420 ; g) F. Pohlki, S. Doye, Chem. Soc. Rev. 2003, 32, 104-114.

[24] a) H. Tang, N. Arulsamy, M. Radosz, Y. Shen, N. V. Tsarevsky, W. A. Braunecker, W. Tang, K. Matyjaszewski, J. Am. Chem. Soc. 2006, 128, 16277 16285 ; b) M. J. L. Tschan, C. M. Thomas, H. Strub, J. F. Carpentier, Adv. Synth. Catal. 2009, 351, 24962505 ; c) K. E. Nosova, E. V. Tretyakov, G. V. Romanenko, V. I. Ovcharenko, Russ. Chem.. Bull. Int. Ed. 2003, 52, 2231-2234.

[25] E. D. Blue, A. Davis, D. Conner, T. B. Gunnoe, P. D. Boyle, P. S. White, J. Am. Chem. Soc. 2003, 125, 94359441.

[26] CCDC-783449 for $\mathbf{1 0}$ and CCDC-783450 for $\mathbf{1 1 .}$ These data can be obtained free of charge from The Cambridge Crystallographic Data Centre www.ccdc.cam.ac.uk:data_request/cif.

[27] a) J. J. Allen, A. R. Barron, Dalton Trans. 2009, 878890 ; b) A. Boni, G. Pampaloni, R. Peloso, D. Belleti, C. Graiff, A. Tiripicchio, J. Organomet. Chem. 2006, 691, 5602-5609 ; c) B. F. Straub, I. Gruber, F. Rominger, P. Hofmann, J. Organomet. Chem. 2003, 684, 124-143 ; d) B. F. Straub, F. Eisenträger, P. Hofmann, Chem. Commun. 1999, 2507-2508 ; e) J. Min, J. Benet-Buchholz, R. Boese, Chem. Commun. 1998, 2751-2752 ; f) D. D. LeCloux, R. Davydov, S. J. Lippard, Inorg. Chem. 1998, 37, 6814-6826 ; g) M. Pasquali, C. Floriani, A. Gaetani-Manfredotti, A. Chiesi-Villa, J. Am. Chem. Soc. 1978, 100, 4918-4919.
[28] a) C. Di Nicola, C. Pettinari, M. Ricciutelli, B. W. Skelton, N. Somers, A. H. White, Inorg. Chim. Acta 2005, 258, 4003-4008 ; b) K. H. Lin, Q. Xie, R. N. Yang, L. P. Xing, D. M. Jin, Jiegou Huахиe 2002, 21, 51-54 ; c) P. Comba, C. Katsichtis, B. Nuber, H. Pritzkow, Eur. J. Inorg. Chem. 1999, 777-783.

[29] For selected examples of copper hemilability: a) A. Boni, G. Pampaloni, R. Peloso, D. Belleti, C. Graiff, A. Tiripichio, J. Organomet. Chem. 2006, 691, 56025609 ; b) J. S. Lewis, J. Zweit, P. J. Blower, Polyhedron 1998, 17, 513-517 ; c) C. Pettinari, F. Marchetti, R. Polimante, A. Cingolani, G. Portalone, M. Colapietro, Inorg. Chim. Acta 1996, 249, 215-229 
